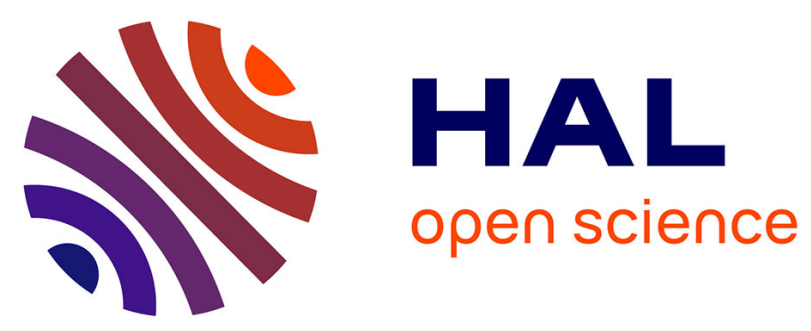

\title{
Experimental Phase-equilibrium Constraints on the Phonolite Magmatic System of Erebus Volcano, Antarctica
}

Yves Moussallam, Clive Oppenheimer, Bruno Scaillet, Philip R. Kyle

\section{To cite this version:}

Yves Moussallam, Clive Oppenheimer, Bruno Scaillet, Philip R. Kyle. Experimental Phase-equilibrium Constraints on the Phonolite Magmatic System of Erebus Volcano, Antarctica. Journal of Petrology, 2013, 54 (7), pp.1285-1307. 10.1093/petrology/egt012 . insu-00813668

\section{HAL Id: insu-00813668 https://hal-insu.archives-ouvertes.fr/insu-00813668}

Submitted on 4 May 2014

HAL is a multi-disciplinary open access archive for the deposit and dissemination of scientific research documents, whether they are published or not. The documents may come from teaching and research institutions in France or abroad, or from public or private research centers.
L'archive ouverte pluridisciplinaire HAL, est destinée au dépôt et à la diffusion de documents scientifiques de niveau recherche, publiés ou non, émanant des établissements d'enseignement et de recherche français ou étrangers, des laboratoires publics ou privés.

\section{(1) (1) $\$$}

Distributed under a Creative Commons Attribution - NonCommercial - NoDerivatives| 4.0 


\title{
Experimental Phase-equilibrium Constraints on the Phonolite Magmatic System of Erebus Volcano, Antarctica
}

1. Yves Moussallam ${ }^{1 *}$

2. Clive Oppenheimer ${ }^{1}$

3. Bruno Scaillet ${ }^{2}$ and

4. Philip R. Kyle ${ }^{3}$

${ }^{1}$ Department of Geography, University of Cambridge, Downing Place, Cambridge CB2 $3 E N, U K$

${ }^{2}$ Institut des Sciences de la Terre d'Orléans, Université D'orléans-CNRS-BRGM, $1 \mathrm{~A}$ RUE DE LA Férollerie, 45071 Orléans Cedex 2, France

${ }^{3}$ Department of Earth and Environmental Science, New Mexico Institute of Mining and Technology, 801 Leroy Place, Socorro, NM 87801, USA

\begin{abstract}
Field observations and petrological studies have recently advanced understanding of the magmatic system of Erebus volcano, renowned for its sustained $\mathrm{CO}_{2}$-rich degassing, and long-lived phonolitic lava lake. However, this body of work has highlighted uncertainty in several key parameters, including the magma temperature, redox state and the depth of the reservoir presumed to maintain the lava lake. Here, we use experimentally determined phase equilibria to constrain these unknowns. The experiments ranged in temperature from 900 to $1025^{\circ} \mathrm{C}$, in pressure from atmospheric to $300 \mathrm{MPa}$, in water content from 0 to $8 \mathrm{wt} \%$, and in oxygen fugacity from $\mathrm{NNO}+4$ (where $\mathrm{NNO}$ is nickel-nickel oxide) to QFM - 2 (where QFM is quartz-fayalite-magnetite). The natural system was experimentally reproduced at 950 $\pm 25^{\circ} \mathrm{C}$, a pressure below $200 \mathrm{MPa}$, redox conditions between QFM and QFM - 1, and remarkably low water contents of less than $0.5 \mathrm{wt} \%$. These findings help in understanding petrological observations, including melt inclusion data, as well as the measured composition of gas emissions from the lava lake. Biotite and amphibole appear in the crystallization sequence at around $925^{\circ} \mathrm{C}$, even under very dry conditions (biotite). Both biotite and amphibole are absent in the phonolites erupted over the last $20 \mathrm{kyr}$ at Erebus. The constant abundance of anorthoclase observed in the erupted lavas and bombs indicates that the shallow magmatic system feeding the Erebus lava lake (below pressures of $200 \mathrm{MPa}$ ) has been thermally buffered at $950 \pm 25^{\circ} \mathrm{C}$ over this time period, possibly reflecting steady-state connection with the deep feeding system rooted in the mantle. Combined with recent seismological data, our results suggest that if a large phonolitic reservoir exists, then it should lie in the depth range $4-7 \cdot 5 \mathrm{~km}$. The tight constraints on temperature and redox conditions will be valuable for future thermodynamical and rheological modelling.
\end{abstract}

Key words : Erebus ; phonolite ; phase equilibrium ; lava lake ; $\mathrm{CO}_{2}$; degassing

\section{Introduction}

Erebus represents an archetype of an open-vent volcano, with the uppermost part of its magmatic conduit exposed at the surface as an active lava lake. A conceptual model has been 
proposed to explain the persistence of the convecting lava lake, with the lake connected to a source reservoir via a narrow ( $<10 \mathrm{~m}$ radius) conduit in which there is a counter flow of denser degassed magma and buoyant, volatile-rich and un-degassed magma (Calkins et al., 2008; Oppenheimer et al., 2009). Numerical models of magma convection in the conduit and its relationship with the lava lake have been described by Molina et al. (2012); conceptual models of such behaviour date back further (e.g. Francis et al., 1993; Kazahaya et al., 1994). Such models, however, still require validation from field-based observations and experimental studies. Magma temperature and reservoir depth are two crucial parameters required to understand the system and for the further development of modelling endeavours.

The first estimate of lava temperature at Erebus was made by training an optical pyrometer on incandescent cracks in the lava lake (viewed from the crater rim), and suggested a magma temperature of $\sim 1000^{\circ} \mathrm{C}$ (Kyle, 1977). This is consistent with olivine-clinopyroxene thermometry (Caldwell \& Kyle, 1994) and was also found to be the temperature at which anorthoclase-hosted melt inclusions in Erebus phonolite anneal during heating stage measurements at $0 \cdot 10 \mathrm{MPa}$ (Dunbar et al., 1994). The only other field-based measurement indicates a minimum temperature of $923^{\circ} \mathrm{C}$, using mid-infrared imaging with a hand-held thermal camera operated from the crater rim (Calkins et al., 2008). More recently, thermodynamic calculations based on measurements of $\mathrm{CO}, \mathrm{CO}_{2}, \mathrm{SO}_{2}$ and $\mathrm{OCS}$ in the gases emitted from the lava lake have suggested an equilibrium gas temperature of $1080^{\circ} \mathrm{C}$ (Burgisser et al., 2012).

The second significant unknown is the depth of the hypothesized magma chamber that feeds the lava lake. Oppenheimer et al. (2011) modelled anorthoclase-hosted melt inclusion $\mathrm{CO}_{2}$ and $\mathrm{H}_{2} \mathrm{O}$ abundances and computed degassing paths to the surface to suggest that phonolite is present from depths of $\sim 10 \mathrm{~km}$ up to the surface, but this hardly constrains the location of any suspected magma reservoir feeding the summit lava lake. Seismic illumination from Strombolian eruption coda and active source tomography experiments were used to image the subsurface in the summit region $(<4 \mathrm{~km}$ depth below the surface; Chaput et al., 2012; Zandomeneghi et al., 2013), revealing a complex shallow plumbing system but no large single reservoir.

Here, we use an experimental approach to constrain the nature of the shallow plumbing system of Erebus in terms of pressure-temperature-volatile space. Our experimental strategy is two-fold: the first step consists of exploring lava lake conditions using an Erebus lava bomb as starting material, and spanning a temperature range from $1025^{\circ} \mathrm{C}$ to $905^{\circ} \mathrm{C}$ at an oxygen fugacity $\left(f \mathrm{O}_{2}\right)$ imposed by a controlled atmosphere with a $\mathrm{CO}_{2} / \mathrm{CO}$ ratio of $15 \mathrm{~mol} \mathrm{~mol}^{-1}$ (corresponding to $\sim \mathrm{QFM}-0.7$ to QFM - 1; where QFM refers to the quartz-fayalitemagnetite solid buffer in log units). The second set of experiments uses the same natural sample as starting material but explores the pressure range from 20 to $300 \mathrm{MPa}$, at temperatures between 900 and $1000^{\circ} \mathrm{C}$ and oxygen fugacity from QFM -2 to $\mathrm{NNO}+4$ (NNO referring to the $\mathrm{Ni}-\mathrm{NiO}$ solid buffer, which is $\sim 0.7 \log$ units of $f \mathrm{O}_{2}$ more oxidized than QFM).

\section{Volcanological background}

Erebus, the southernmost active volcano in the world $\left(3794 \mathrm{~m}, 77 \cdot 58^{\circ} \mathrm{S}, 161 \cdot 17^{\circ} \mathrm{E}\right)$, is a composite intraplate stratovolcano located on Ross Island, Antarctica (Fig. 1a). It belongs to the Erebus volcanic province, which constitutes part of the McMurdo Volcanic Group (Kyle, $1990 a, 1990 b$; Kyle et al., 1992). The regional volcanism is related to rifting of the western 
margin of the Ross Embayment (part of the West Antarctic Rift System) and a hypothesized mantle plume (Kyle et al., 1992). P-wave tomography reveals a low-velocity anomaly extending to $\sim 400 \mathrm{~km}$ depth, providing some evidence for such a plume (Gupta et al., 2009).
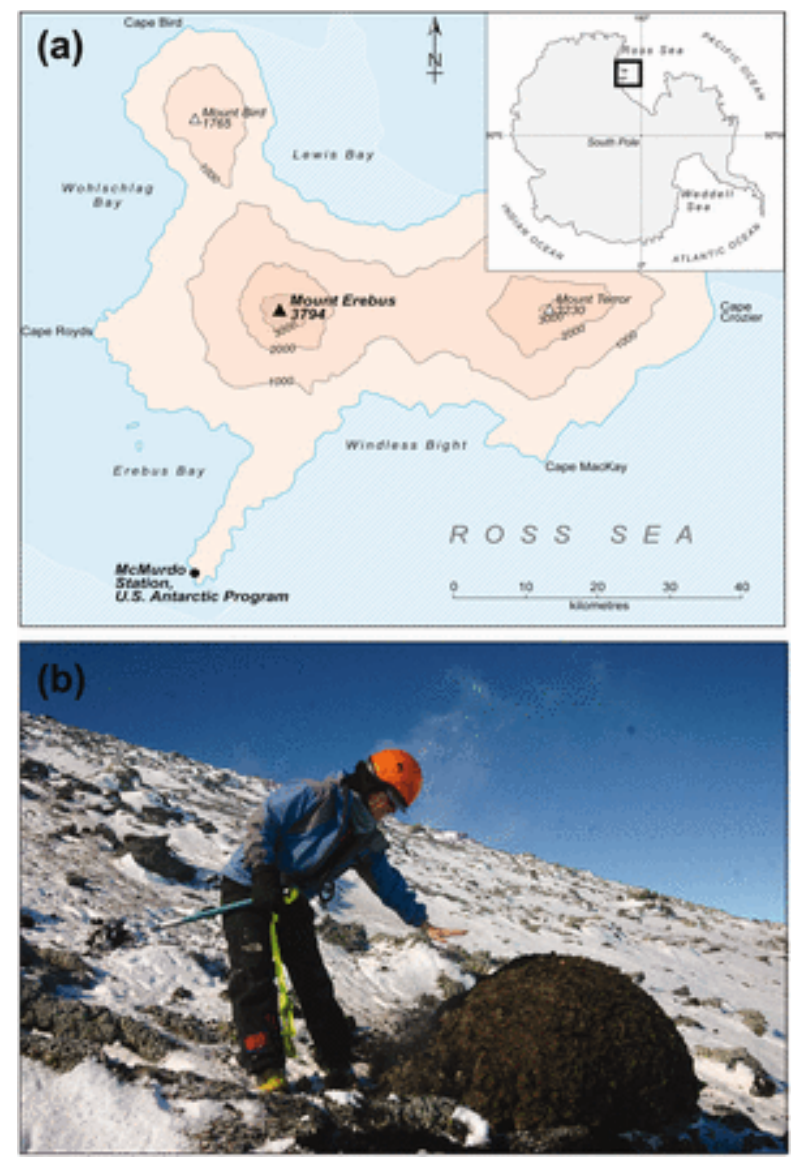

Fig. 1 : (a) Location map of Erebus volcano on Ross Island. Inset shows the location of Ross Island within the Antarctic continent. (b) A freshly erupted volcanic bomb on the flank of Erebus volcano, December 2005.

The first of three stages of eruptive activity at Erebus volcano began $~ 1.3 \mathrm{Myr}$ ago (Esser $e t$ $a l ., 2004)$. These three stages have been documented by repeated ${ }^{40} \mathrm{Ar} /{ }^{39} \mathrm{Ar}$ dating campaigns (Esser et al., 2004; Harpel et al., 2004, 2008; Kelly et al., 2008a) and consist of an initial shield-building phase with eruption of basanite $(1 \cdot 3-1 \cdot 0 \mathrm{Ma})$, followed by a cone-building phase dominated by phonotephrites, later partially destroyed by a caldera collapse event ( $\sim 750 \mathrm{kyr}$ ago), and finally the construction of the modern Erebus cone by anorthoclasephyric tephriphonolite and phonolite lavas, starting $250 \mathrm{kyr}$ ago and continuing to the present (Kelly et al., 2008a).

Acknowledging the long gaps in field observations, the present volcanic activity appears to have persisted since Erebus volcano was first witnessed and described by James Clark Ross in 1841. The active lava lake sits in the Inner Crater of the Main Crater at the volcano's summit (Kyle et al., 1982, 1994; Oppenheimer et al., 2009). The lava lake is sporadically disturbed by Strombolian eruptions associated with the rupture of large $\mathrm{CO}_{2}$-rich gas slugs at the lake surface (Aster et al., 2008; Gerst et al., 2008, 2013; Oppenheimer et al., 2011). Some of these 
explosions are large enough to expel all the lava in the lake and eject bombs onto the crater rim, where they can be collected for petrological studies (Kelly et al., 2008b).

\section{Experimental Methods}

\section{Starting material}

The starting material (ERE 97018) is a phonolitic bomb erupted in 1997 and collected on the crater rim. The ambient air and ground temperature ensured rapid quenching (Fig. 1b). This particular sample was used because of the large sample size $(5 \mathrm{~kg})$, which was jaw crushed and ground to a fine $(5-10 \mu \mathrm{m})$ homogeneous powder with a tungsten carbide swing mill (Eschenbacher, 1998). The large amount of homogenized sample powder provides reasonable assurance that the measured bulk-rock composition is representative of the magma composition, minimizing the effect of the abundant anorthoclase megacrysts (typically a few centimetres in length).

Table 1 summarizes previous glass and whole-rock analyses of the sample from Eschenbacher (1998) together with representative analyses of minerals present in Erebus bombs erupted over the last 30 years (Kelly et al., 2008b). The bombs are of phonolitic composition based on the total alkalis-silica (TAS) classification (Le Bas et al., 1986). The natural modal phase proportion is $65.5 \%$ matrix glass, $30.6 \%$ anorthoclase feldspar, $1.7 \%$ titanomagnetite, $1.3 \%$ olivine, $0.4 \%$ clinopyroxene and $0.6 \%$ fluorapatite (Kelly et al., 2008b). Phonolite lava bombs are highly vesicular and display an extreme phaneritic texture with anorthoclase crystals up to around $7 \mathrm{~cm}$ in length. The groundmass is mostly glassy, essentially microlite free, and contains small amounts of olivine, opaque oxides, clinopyroxene, and fluorapatite. The clinopyroxenes in some bombs can be up to $1 \mathrm{~cm}$ in length. Using a single sample as starting material for both 1 atmosphere $(0 \cdot 10 \mathrm{MPa})$ and pressurized experiments to re-create the lava lake and the reservoir is justified as the composition of phonolite erupted in the last $20 \mathrm{kyr}$ at Erebus is virtually constant, and both bombs erupted from the lava lake and large lava flows on the volcano flanks have exactly the same mineral assemblage (Kelly et al., $2008 b$ ). This implies that the natural phase assemblage is at equilibrium both in the reservoir and in the lava lake. 
Table 1 : Electron microprobe analysis (wt \%) of bomb sample ERE 97018 erupted from Erebus volcano and used in the experimental studies

\begin{tabular}{|c|c|c|c|c|c|c|c|c|c|c|c|c|c|c|c|}
\hline \multirow[b]{2}{*}{$n:$} & \multicolumn{2}{|c|}{ SM } & \multicolumn{2}{|c|}{ WR } & \multicolumn{2}{|c|}{ MG } & \multicolumn{2}{|c|}{ OL } & \multicolumn{2}{|c|}{ CPX } & \multirow{2}{*}{$\begin{array}{c}\text { Anorth } \\
755\end{array}$} & \multicolumn{2}{|c|}{ Ti-mt } & \multicolumn{2}{|c|}{ F-ap } \\
\hline & 15 & SD & 2 & SD & 18 & SD & 67 & SD & 19 & SD & & 643 & SD & 63 & SD \\
\hline $\mathrm{SiO}_{2}$ & $56 \cdot 05$ & 0.33 & $56 \cdot 23$ & $30 \cdot 265$ & $55 \cdot 11$ & 0.60 & $34 \cdot 80$ & -0.43 & $50 \cdot 89$ & $-0 \cdot 3$ & $62 \cdot 87$ & & & 0.35 & $-0 \cdot 1$ \\
\hline $\mathrm{CiO}_{2}$ & 0.96 & 0.04 & 0.99 & 0.011 & 1.03 & 0.03 & & & $1 \cdot 35$ & $-0 \cdot 25$ & & $24 \cdot 52$ & $2-0.51$ & & \\
\hline $\mathrm{Al}_{2} \mathrm{O}_{3}$ & $19 \cdot 22$ & $0 \cdot 27$ & $19 \cdot 82$ & 20.131 & $19 \cdot 85$ & 0.31 & 0.01 & $-0 \cdot 01$ & $2 \cdot 81$ & $-0 \cdot 12$ & 81 & $2 \cdot 27$ & $-0 \cdot 17$ & & \\
\hline $\mathrm{eO}_{\mathrm{T}}$ & $5 \cdot 24$ & $0 \cdot 18$ & $5 \cdot 35$ & 0.015 & $5 \cdot 34$ & 0.07 & $38 \cdot 33$ & $3-0 \cdot 6$ & $9 \cdot 54$ & $-0 \cdot 16$ & $0 \cdot 19$ & $67 \cdot 87$ & $7-1 \cdot 36$ & 0.51 & -0 \\
\hline $\mathrm{AnO}$ & $0 \cdot 23$ & 0.08 & $0 \cdot 23$ & $0.00 \mathrm{C}$ & $0 \cdot 27$ & 0.06 & $2 \cdot 45$ & $-0 \cdot 15$ & $0 \cdot 65$ & $-0 \cdot 03$ & & 1.76 & $-0 \cdot 11$ & $0 \cdot 11$ & $-0 \cdot 0$ \\
\hline $\mathrm{ggO}$ & 0.91 & 0.03 & $0 \cdot 88$ & 0.010 & $0 \cdot 83$ & 0.03 & $23 \cdot 53$ & $3-0.33$ & $12 \cdot 23$ & $-0 \cdot 2$ & & $2 \cdot 89$ & -0.08 & & \\
\hline $\mathrm{CaO}$ & $2 \cdot 60$ & 0.07 & $2 \cdot 68$ & 0.011 & $1 \cdot 88$ & 0.08 & $0 \cdot 50$ & -0.09 & $21 \cdot 13$ & $-0 \cdot 33$ & $3 \cdot 36$ & & & 53.67 & -0 \\
\hline $\mathrm{a}_{2} \mathrm{O}$ & $7 \cdot 90$ & $0 \cdot 28$ & $8 \cdot 38$ & 0.019 & $9 \cdot 07$ & $0 \cdot 19$ & & & 0.93 & $-0 \cdot 08$ & 7.57 & & & $0 \cdot 12$ & -0 \\
\hline $\mathrm{K}_{2} \mathrm{O}$ & $4 \cdot 56$ & $0 \cdot 11$ & $4 \cdot 51$ & 0.055 & $5 \cdot 65$ & 0.05 & & & & & $3 \cdot 12$ & & & & \\
\hline${ }_{2} \mathrm{O}_{5}$ & 0.40 & 0.07 & 0.42 & $0.00 \mathrm{c}$ & $0 \cdot 30$ & 0.04 & & & & & & & & 41.07 & -0 \\
\hline otal & 98.09 & & $99 \cdot 61$ & & $99 \cdot 33$ & & $99 \cdot 62$ & & 99.53 & & 99.92 & $99 \cdot 31$ & & $95 \cdot 83$ & \\
\hline
\end{tabular}

SM, starting material; WR, whole-rock; MG, matrix glass; OL, olivine; CPX, clinopyroxene; Anorth, anorthoclase; Ti-mt, titanomagnetite; F-ap, fluorapatite. Glass and whole-rock analyses are from Eschenbacher (1998). Representative analyses of olivine, clinopyroxene, anorthoclase, titanomagnetite and fluorapatite in lava bombs erupted from Erebus volcano between December 1972 and January 2004 are from Kelly et al. (2008b). F content of apatite is $3.06 \mathrm{wt} \%$.

Powder $(10 \mathrm{~g})$ from sample ERE 97018 was dried at $140^{\circ} \mathrm{C}$ overnight, then placed in a platinum crucible, heated at $1400^{\circ} \mathrm{C}$ in a 1 atmosphere $(0 \cdot 1 \mathrm{MPa})$ furnace for $2 \mathrm{~h}$, and then quenched. The glass retrieved was pulverized (in an agate grinder) to a fine powder and heated once more under the same conditions for an additional $2 \mathrm{~h}$. The highly oxidizing conditions (open atmosphere) minimize the amount of $\mathrm{Fe}$ loss to the crucible, and convert most of the iron to $\mathrm{Fe}^{3+}$. After quenching (in water at room temperature) the glass was imaged by scanning electron microscope (SEM) to verify the absence of crystals. Subsequent analysis by electron microprobe also confirmed the homogeneity of the glass (Table 1) and confirmed that no Fe loss, and only minimal Na loss, had occurred. This starting glass was finely ground and used for all experiments.

Controlled-atmosphere furnace at 1 atmosphere

To re-create the magmatic conditions of the lava lake we used a controlled-atmosphere furnace at the Department of Earth Sciences, University of Cambridge. The furnace operates at atmospheric pressure ( $0.1 \mathrm{MPa})$ and is heated by a silicon carbide resistance wire wrapped around an aluminium cylinder. The current is controlled by a Eurotherm 2404 series regulator able to maintain a constant temperature $\left( \pm 2^{\circ} \mathrm{C}\right)$ within the furnace. The cooling system consists of a constant flow of water circulating within the furnace.

For each experiment, $50 \mathrm{mg}$ of sample was mixed with a liquid glue (UHU brand 'twist and glue') and placed on a thin platinum wire tied to two thicker platinum wires located at the end of a ceramic can (sample holder). The sample was then introduced in the furnace and heated to the required temperature. During heating the glue evaporates leaving the sample on the thin 
platinum wire. The sample temperature was monitored continuously by a thermocouple located $1 \mathrm{~cm}$ from the sample. A controlled mixture of $\mathrm{CO}$ and $\mathrm{CO}_{2}$ gases was circulated through the furnace and monitored during the experiments by calibrated flow meters. At the end of each experiment, the sample was dropped and quenched in a container of deionized water, so as to preserve the chemical and textural equilibrium attained. The drop was initiated by short-circuiting the thin platinum wire by passing a current through the thick platinum wires. To minimize Fe loss to the Pt wire (forming Fe-Pt alloy), all Pt wires were presaturated with iron. Sample powder was pasted on each wire, melted at $1200^{\circ} \mathrm{C}$ under reduced conditions $\left[\log \left(f \mathrm{O}_{2}\right)=-9 \cdot 6 ; \Delta \mathrm{QFM}=-1 \cdot 4\right]$ and left to equilibrate for 2 days. The wires were then placed in hydrofluoric acid to dissolve any adhering glass and only then used for the phase-equilibrium experiments. After each experiment, the charge with its platinum wire was embedded in epoxy resin and polished for SEM and microprobe analysis.

Seven equilibrium experiments were carried out covering a temperature range from 905 to $1025^{\circ} \mathrm{C}$. All experiments lasted about 4 days and the gas flux was maintained at a $\mathrm{CO}_{2} / \mathrm{CO}$ ratio of $15 \mathrm{~mol} \mathrm{~mol}^{-1}\left[\log \left(f \mathrm{O}_{2}\right)\right.$, equivalent to QFM - 0.7 to QFM - 1]. This gas ratio was used as it is typical of the ratio measured for emissions from the lava lake by open-path Fourier transform infrared (FTIR) spectroscopy (Oppenheimer \& Kyle, 2008; Oppenheimer et $a l ., 2009,2011)$. The stable $\mathrm{CO}_{2} / \mathrm{CO}$ ratio observed in the gas emission, the abundance of hydrogen detected in the gas and aerosol plume when it reaches the crater rim (Moussallam et al., 2012), and their compatibility with redox conditions computed for the lava lake from mineral compositional data provide very strong evidence that the magmatic gas is effectively quenched on sudden cooling in the atmosphere (in thermodynamical terms, the $\mathrm{CO}_{2} / \mathrm{CO}$ and $\mathrm{H}_{2} \mathrm{O} / \mathrm{H}_{2}$ contents of the plume are far from equilibrium in air).

Internally heated pressure vessels

To investigate the phonolite magmatic system that feeds the lava lake, we performed a series of phase-equilibrium experiments at a range of pressures (20-300 MPa), temperatures (900$1000^{\circ} \mathrm{C}$ ) and $X_{\mathrm{H} 2 \mathrm{O}}$ (mole fraction of water in the fluid phase, from near zero to unity) under reduced conditions $\left(f \mathrm{O}_{2} \approx \mathrm{QFM}\right.$ or below).

We used internally heated pressure vessels at the ISTO-CNRS laboratory in Orléans, which can reach pressures of up to $400 \mathrm{MPa}$ under controlled temperature (up to $1200^{\circ} \mathrm{C}$ ) and oxygen fugacity conditions. The vessel was pressurized using an argon-hydrogen gas mixture as the pressure medium to control redox state (Scaillet et al., 1992). Heating was applied by a double-wound molybdenum furnace creating a stable 'hot-spot' zone. Two S-type

thermocouples located on either side of this $5 \mathrm{~cm}$ wide 'hot-spot' permitted precise control of the heating resistances, thus preventing the establishment of thermal gradients.

Experimental charges consisted of natural anhydrous sample powder (30 mg) with $X_{\mathrm{H} 2 \mathrm{O} \text { loaded }}$ [the mole fraction of $\mathrm{H}_{2} \mathrm{O}$ added to the capsule, $\mathrm{H}_{2} \mathrm{O} /\left(\mathrm{H}_{2} \mathrm{O}+\mathrm{CO}_{2}\right)$ ] varying from zero to unity (i.e. pure $\mathrm{CO}_{2}$ to pure $\mathrm{H}_{2} \mathrm{O}$ ), which was loaded in gold capsules $(2 \mathrm{~cm}$ in length, $2.5 \mathrm{~mm}$ inner diameter and $2.9 \mathrm{~mm}$ outer diameter). $\mathrm{CO}_{2}$ was added to the capsule contents in the form of silver oxalate. The capsules were wrapped in liquid nitrogen-soaked tissue to prevent water loss and welded shut. For each experiment, six capsules and a sensor were placed in a sample holder hung by a thin Pt wire. The temperature gradient along the 'hot-spot' zone where the capsules were located was always $<2^{\circ} \mathrm{C}$. Rapid quenching was ensured by passing an electrical current to the holding Pt wire (Di Carlo et al., 2006), so that the sample dropped into the cold part of the vessel, providing a cooling rate of $>100^{\circ} \mathrm{C} \mathrm{s}^{-1}$. The redox state was 
measured in situ by a cobalt-cobalt oxide redox sensor (Taylor et al., 1992; Di Carlo et al., 2006) placed with the capsules in the sample holder during each experiment. After each experiment, the capsules were weighed to verify that no leakage had occurred. They were then opened and part of the charge (as a single fragment) was embedded in epoxy resin and polished for SEM and microprobe analysis.

We conducted a total of 66 phase-equilibrium experiments. The strategy was to produce a complete isobaric section at $100 \mathrm{MPa}$, in the temperature interval $900-1000^{\circ} \mathrm{C}$. We then varied the pressure from 20 to $300 \mathrm{MPa}$ at a magmatic temperature of $950^{\circ} \mathrm{C}$ as inferred from the isobaric experiments. Most experiments were performed at oxygen fugacity conditions close to the QFM buffer, or below. A subset of experiments were conducted under oxidized condition $\left.\log \left(\mathrm{fO}_{2}\right)=\mathrm{NNO}+4\right]$ to evaluate the effect of oxygen fugacity on phase equilibria and compositions, in particular in the liquid. We chose the QFM buffer as the value for oxygen fugacity based on gas measurements made at the crater rim by Oppenheimer et al. (2011), who reported redox conditions ranging from NNO (for gases associated with Strombolian eruptions) to QFM - 1 (for passive degassing). These measurements together with chemical modelling (Burgisser et al., 2012) suggest more oxidizing conditions at depth.

\section{Analytical Techniques}

All experimental products were first examined by reflected light optical microscope and then by SEM. The SEM imaging ensured homogeneity in terms of phase distribution, and highquality images were obtained to estimate modal proportions. All phases present were determined by semi-quantitative energy-dispersive spectroscopy. Detailed image analyses using the ImageJ freeware (http://rsbweb.nih.gov/ij/) were performed to estimate the modal proportion of each phase. Although most phases were easy to threshold from the SEM image and therefore yield a good estimate of their modal abundance, feldspars were often harder to differentiate from the background owing to the similarity of their composition to the glass. We therefore developed a technique to calculate the proportion of feldspar using a fuzzy algorithm for contrast enhancement, which was better able to distinguish the feldspar from the surrounding glass. Subsequently we used an outlier removal algorithm to suppress noise (mostly misclassified pixels within feldspar). The feldspar modal proportion was then calculated by thresholding in a similar way to that used for the other phases.

A series of 12 experimental supra-liquidus charges run at $1000^{\circ} \mathrm{C}$ in the pressure range 50 $100 \mathrm{MPa}$ produced crystal-free glass and were used as internal standards. The water concentrations of seven of them were determined by FTIR spectroscopy using a Nicolet 6700 spectrometer at ISTO-CNRS, equipped with an infrared microscope (type A590) and an MCT detector. Absorption spectra were acquired with 128 scans in the near-infrared region at a resolution of $4 \mathrm{~cm}^{-1}$. Samples were doubly polished and five measurement spots were analysed on each one to confirm the homogeneity of the water content in the glass. The total amount of water was obtained by the sum of the hydroxyl and molecular water concentrations calculated using the Beer-Lambert law, based on measurements of the $4470 \mathrm{~cm}^{-1}$ and 5210 $\mathrm{cm}^{-1}$ absorption bands. The sample thickness was measured on the infrared microscope and absorption peak heights were measured using a linear background correction. We used molar absorptivity values for phonolite from Carroll \& Blank (1997) of 1.25 and $1 \cdot 1 \mathrm{~L} \mathrm{~mol}^{-1} \mathrm{~cm}^{-1}$ for the 4470 and $5210 \mathrm{~cm}^{-1}$ bands, respectively. 
Electron microprobe analyses were performed using a Cameca SX100 at the Department of Earth Sciences, University of Cambridge. For glass analyses we used an accelerating voltage of $15 \mathrm{kV}$, a beam current of $2 \mathrm{nA}$ and a defocused beam of $10 \mu \mathrm{m}$ whereas for mineral phases we used an accelerating voltage of $10 \mathrm{kV}$, a beam current of $6 \mathrm{nA}$ and a focused beam of 1 $\mu \mathrm{m}$ (details can be found in the Supplementary Data files DR2 and DR3, available for downloading at http:www.petrology.oxfordjournals.org). $\mathrm{Na}$ and $\mathrm{K}$ were analysed first to minimize alkali loss during analysis. Cobalt-cobalt oxide redox sensors were analysed on a Cameca SX50 at ISTO-CNRS using an accelerating voltage of $15 \mathrm{kV}$, a beam current of 20 $\mathrm{nA}$ and a focused beam. The water content of the glass from crystal-bearing charges was estimated using the by-difference method (Devine et al., 1995). The difference from 100\% of the microprobe analyses was calibrated against the $\mathrm{H}_{2} \mathrm{O}$ from the glass standards previously described and analysed together with the crystal-bearing charges during each microprobe session.

\section{Results}

All experimental charges are characterized by a homogeneous distribution of phases except for runs 97018_C_ATM_05 and 97018_C_ATM_06, in which fluorapatite accumulated locally. Attainment of equilibrium is attested to by the euhedral shape of all crystal phases (e.g. Berndt et al., 2001), and geochemical criteria (i.e. homogeneous phase compositions, $\mathrm{Fe} / \mathrm{Mg}$ partition between clinopyroxene and liquid; see below), and reflects the long duration of the experimental runs. In addition to glass and bubbles, the experimental phases identified are anorthoclase feldspar, clinopyroxene, amphibole, biotite, olivine, titanomagnetite and fluorapatite.

\section{1 atmosphere phase equilibria and phase proportions}

Results from the phase-equilibrium experiments at atmospheric pressure are summarized in Table 2 and illustrated in Fig. 2. At $0 \cdot 1 \mathrm{MPa}$ and near QFM -0.9, the first phases to crystallize were fluorapatite and titanomagnetite, with liquidus temperatures higher than $1025^{\circ} \mathrm{C}$ (Table 2). Between 1000 and $1018^{\circ} \mathrm{C}$ anorthoclase crystallizes followed by clinopyroxene at 975 and $1000^{\circ} \mathrm{C}$. Decreasing temperature further increases crystallinity, the system reaching nearly $90 \mathrm{wt} \%$ crystallization at around $900^{\circ} \mathrm{C}$ (Table 2). The latter feature indicates that the dry solidus of the Erebus phonolite is close to the lowest temperature investigated, considering in particular that crystallization is hindered by the relatively slow crystallization kinetics prevailing under $\mathrm{H}_{2} \mathrm{O}$-poor conditions (i.e. the amounts of crystallization under dry conditions should be considered as minima, particularly at low temperatures). The modal composition of the natural sample is closely re-created at $950^{\circ} \mathrm{C}$ and $975^{\circ} \mathrm{C}$, except for olivine, which could not be detected in any of the $0 \cdot 1 \mathrm{MPa}$ experimental run products. 


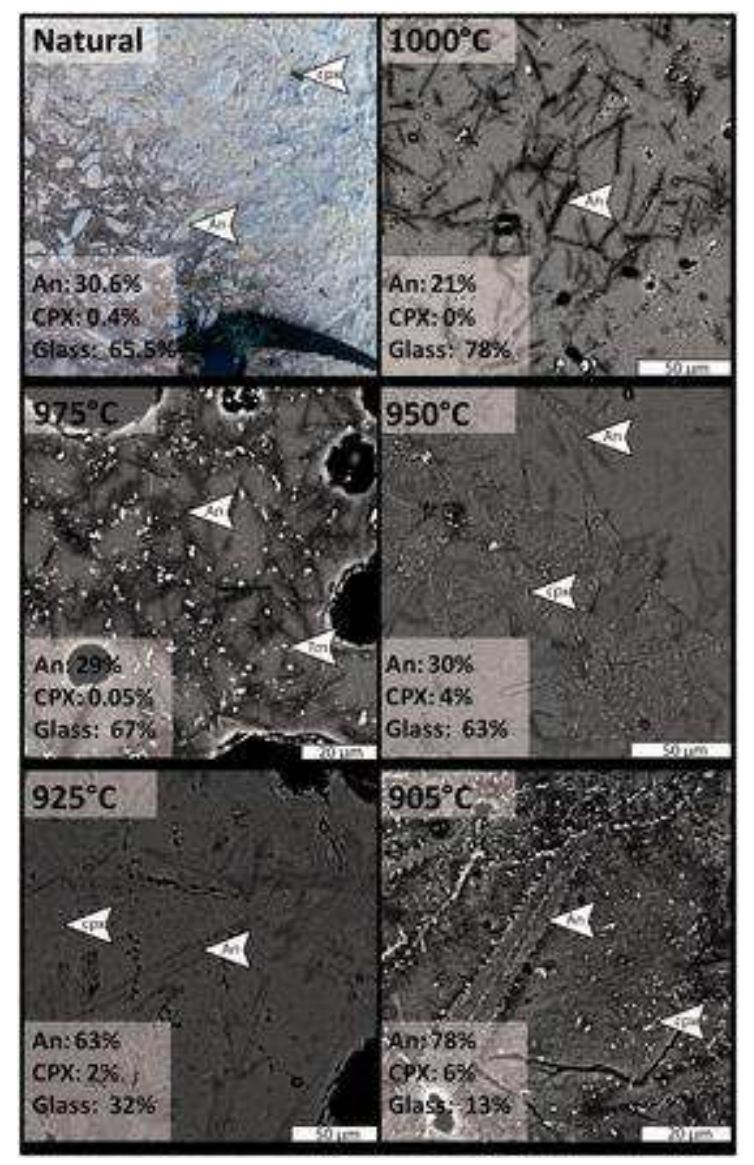

Fig. 2 : Photograph of natural Erebus lava and SEM photomicrographs showing the result of experiments at 1 atmosphere $(0 \cdot 1 \mathrm{MPa})$. The upper left photograph shows the weathered surface of a lava flow on Erebus, revealing the mineralogy at the macro-scale. Anorthoclase crystals appear light grey and clinopyroxenes are black. The head of an ice-axe is shown for scale and is about $20 \mathrm{~cm}$ long. Modal mineralogy is from Kelly et al. (2008b). All other photomicrographs are from experiments C-ATM 01 to 04 and 07. (Note the change in scale between images.) Anorthoclase crystals appear as dark elongated features in highertemperature experiments (at 1000 and $975^{\circ} \mathrm{C}$ ) and in lighter shades of grey surrounded by darker rims in lower-temperature experiments $\left(950-905^{\circ} \mathrm{C}\right)$. An, anorthoclase; CPX, clinopyroxene; Tm, titanomagnetite. 
Table 2 : Conditions and modal mineralogy of experiments conducted at atmospheric pressure, compared with the modal mineralogy of the natural Erebus phonolite (from Kelly et al., 2008b)

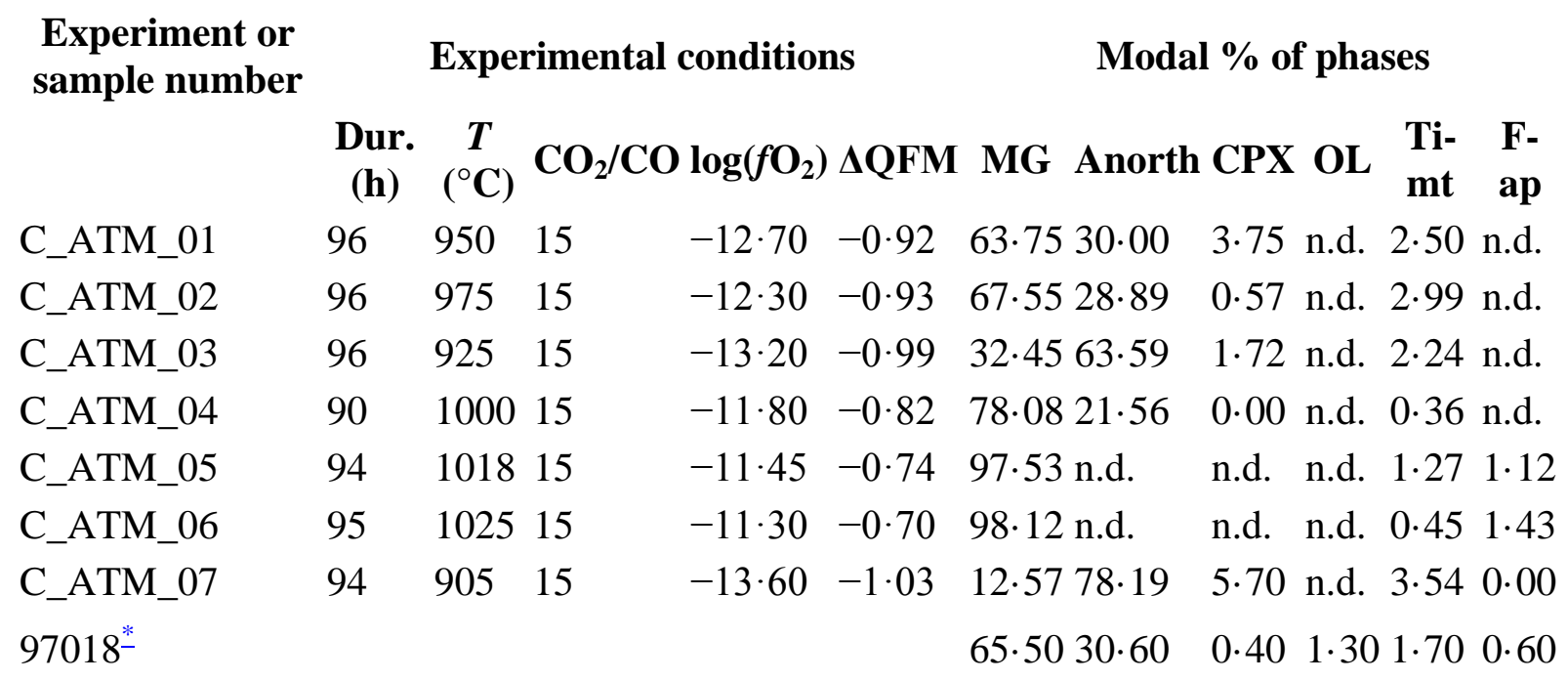

MG, matrix glass; OL, olivine; CPX, clinopyroxene; Anorth, anorthoclase; Ti-mt, titanomagnetite; F-ap, fluorapatite; n.d., not detected.

The calculated modal mineralogy of the natural phonolite from Kelly et al. (2008b).

High-pressure phase equilibria and phase proportions

Table 3 summarizes the modal proportion of phases and associated water content for all runs conducted at pressures from 20 to $300 \mathrm{MPa}$, at or near QFM. The phase relationships are also presented in isobaric and isothermal diagrams (Figs 3 and 4) displaying either the composition of the coexisting fluid phase (Fig. 3) or the amount of water dissolved in the quenched melt (Fig. 4). 

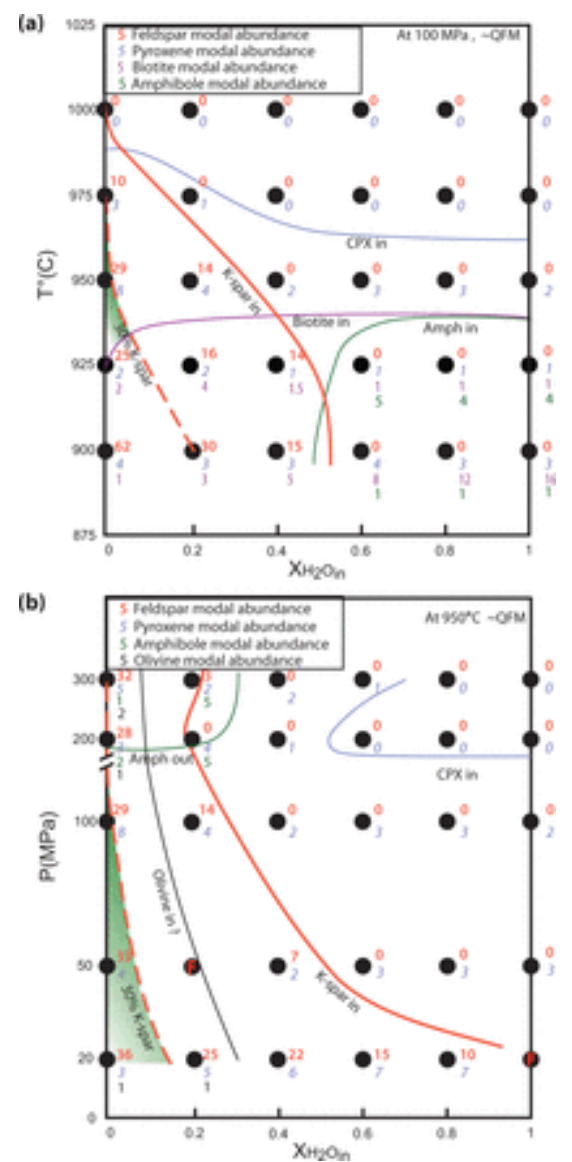

Fig. 3 : (a). Isobaric-polythermal phase relationships of Erebus phonolite at $100 \mathrm{MPa}$ and $\log \left(f \mathrm{O}_{2}\right)$ near QFM. Filled black circles represent the $T-X_{\mathrm{H} 2 \mathrm{Ofluid}}$ conditions of single experimental charges. Phases lie inside their stability field and the proportion of each major phase is given for each experiment. The red dashed line marks $30 \%$ modal proportion of anorthoclase crystals in the run products. The shaded area shows the estimated stability conditions of temperature and $X_{\mathrm{H} 2 \mathrm{Ofluid}}$ (the mole fraction of $\mathrm{H}_{2} \mathrm{O}$ in the fluid phase), as inferred from the phenocryst assemblage of the Erebus phonolite. The natural modal phase proportion is $65.5 \%$ matrix glass, $30.6 \%$ anorthoclase feldspar, $1.7 \%$ titanomagnetite, $1.3 \%$ olivine, $0.4 \%$ clinopyroxene and $0.6 \%$ fluorapatite (Kelly et al., 2008b). (b) Isothermalpolybaric phase relationships of Erebus phonolite at $950^{\circ} \mathrm{C}$ and $\log \left(f \mathrm{O}_{2}\right)$ near QFM. (Note the break in the pressure axis.) The red dashed line marks $30 \%$ modal proportion of anorthoclase crystals in the run products. The shaded area shows the estimated stability conditions of $P$ $X_{\mathrm{H} 2 \mathrm{Ofluid}}$ as inferred from the phenocryst assemblage of the Erebus phonolite. K-spar, potassium feldspar; Amph, amphibole; CPX, clinopyroxene. Runs denoted with ' $F$ ' in the filled black circles represent experiments in which some volatiles were lost. 

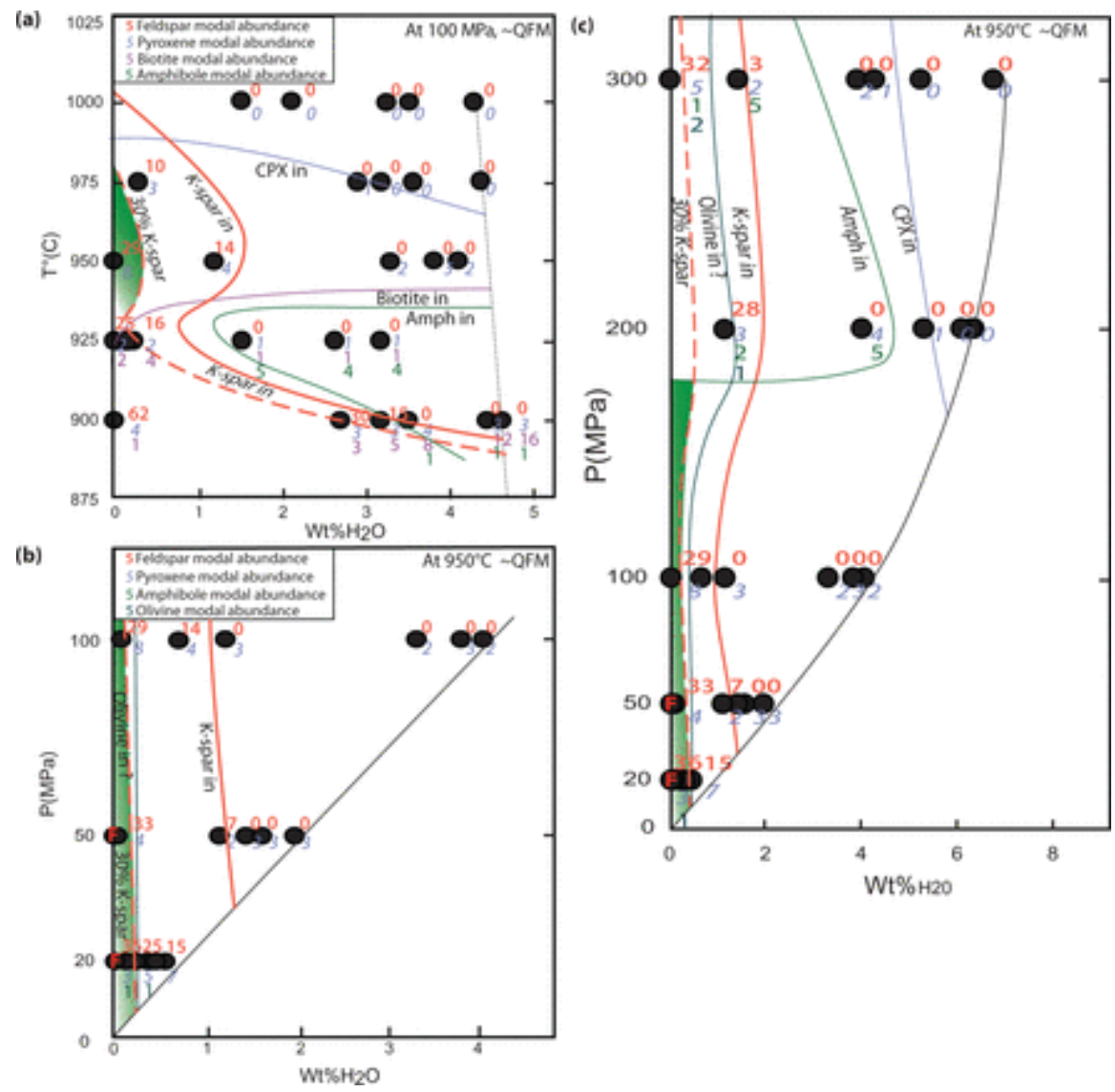

Fig. 4 : (a) Isobaric-polythermal phase relationships of Erebus phonolite at $100 \mathrm{MPa}$ and $\log \left(f \mathrm{O}_{2}\right)$ near QFM. Filled black circles represent the $T$-wt $\% \mathrm{H}_{2} \mathrm{O}_{\text {fluid }}$ location of single experimental charges. Phases lie inside their stability field and the proportion of each major phase is given for each experiment. The dashed red line denotes $30 \%$ modal proportion of anorthoclase crystals in the run products. The shaded area shows the estimated stability conditions of temperature and wt $\% \mathrm{H}_{2} \mathrm{O}_{\text {fluid, }}$, as inferred from the phenocryst assemblage of the Erebus phonolite. The natural modal phase proportion is $65.5 \%$ matrix glass, $30.6 \%$ anorthoclase feldspar, $1.7 \%$ titanomagnetite, $1.3 \%$ olivine, $0.4 \%$ clinopyroxene and $0.6 \%$ fluorapatite (Kelly et al., 2008b). The dotted line represents the solubility of water in phonolites from the Montaña Blanca pumice and Laacher See tephra as a function of temperature at $100 \mathrm{MPa}$ as determined by Schmidt \& Behrens (2008). (b) Isothermalpolybaric phase relationships of Erebus phonolite at $950^{\circ} \mathrm{C}$ and $\log \left(f \mathrm{O}_{2}\right)$ near QFM for pressure up to $100 \mathrm{MPa}$. The red dashed line marks the $30 \%$ modal proportion of anorthoclase crystals in the run products. The shaded area shows the estimated stability conditions of $P-\mathrm{wt}$ $\% \mathrm{H}_{2} \mathrm{O}_{\text {fluid }}$ as inferred from the phenocryst assemblage of the Erebus phonolite. The black line shows the solubility of water in Erebus phonolitic melt as determined from our experimental charges. (See Fig. 2 for abbreviations.) (c) Same as (b) but for pressure up to $300 \mathrm{MPa}$. 
Table 3 : Experimental conditions, calculated water contents and modal mineralogy of all experiments conducted in high-temperature pressure vessels

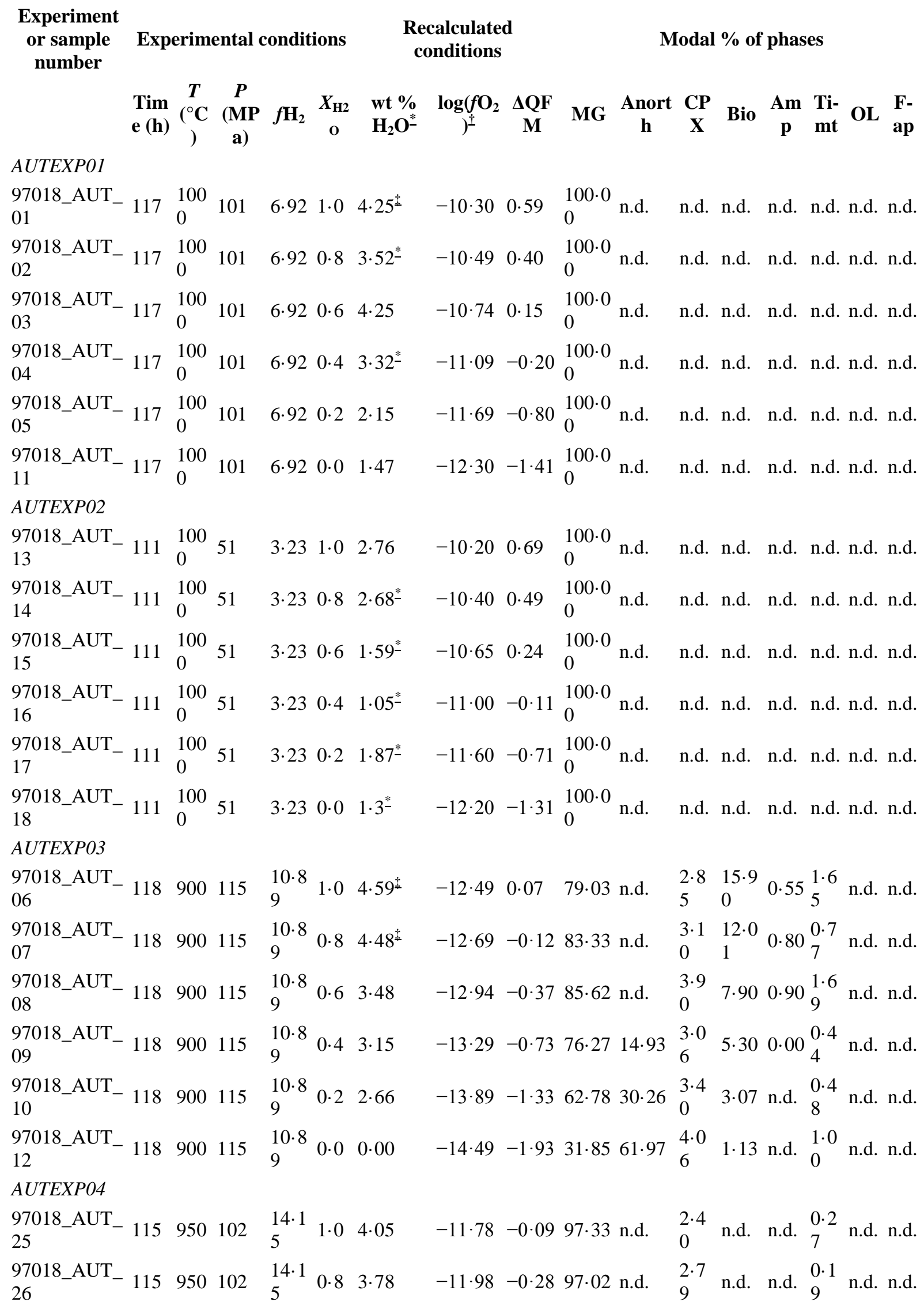




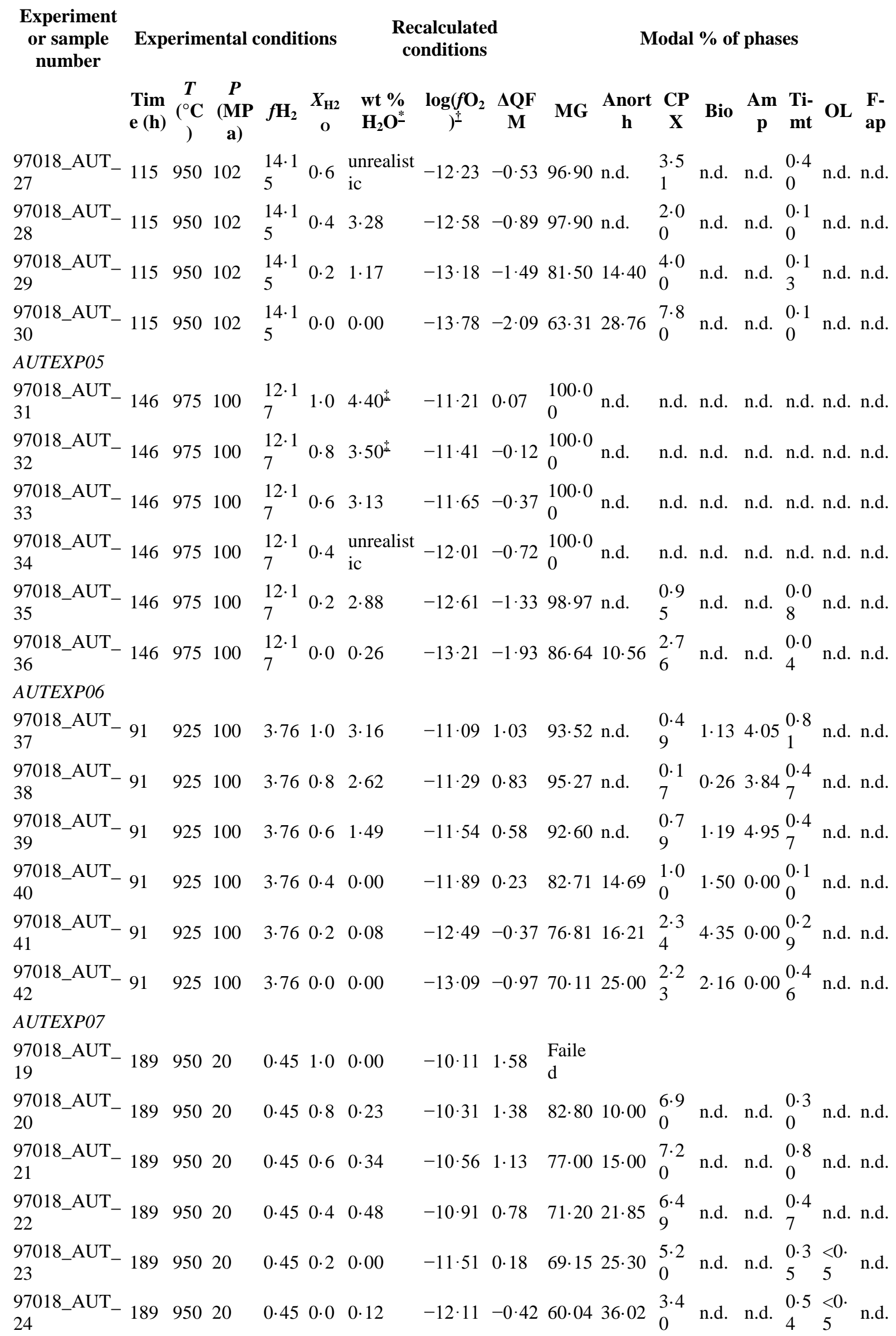

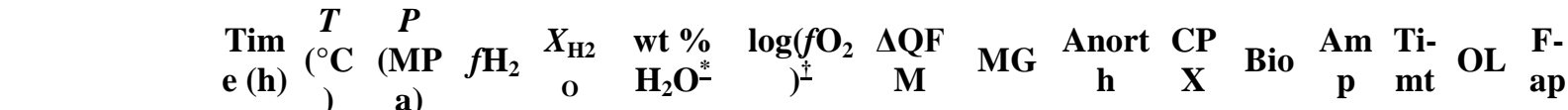

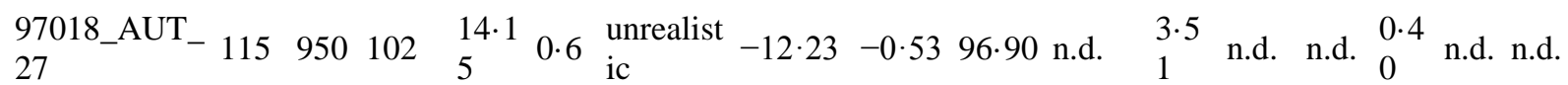

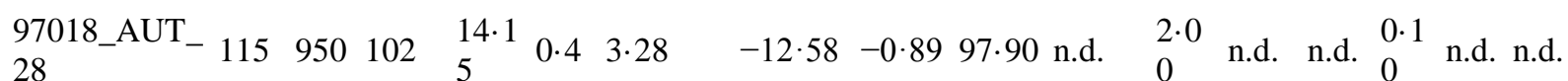

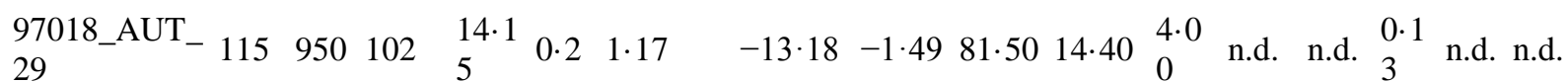
$97018 \_A U T$
30 AUTEXP05

$97018 \_A U T$
31

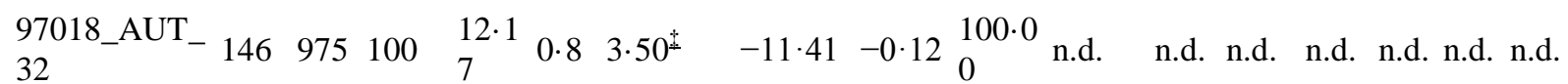

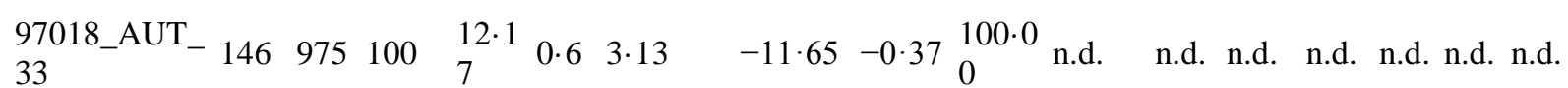
97018_AUT_
34 $97018 \_A U T$
35 $97018 \_A U T$
36 AUTEXP06

97018_AUT_-91 $925100 \quad 3.76$
37 $97018 \_A U T$
38 $97018 \_A U T$
39 $97018 \_A U T$
40 $97018 \_A U T$
41 $97018 \_A U T$
42 AUTEXP07 
Experiment

or sample Experimental conditions

number
Recalculated

conditions
Modal \% of phases

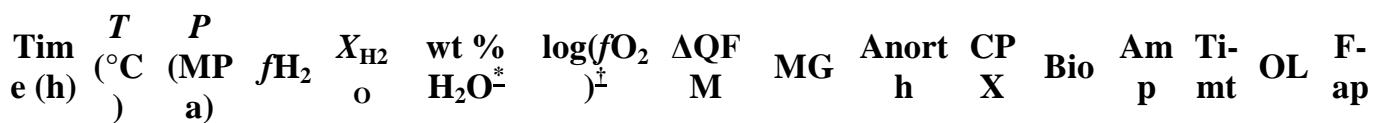

$$
\text { 970 }
$$

$$
\begin{aligned}
& 43 \\
& 970 \\
& 44
\end{aligned}
$$$$
9701
$$

$$
46
$$$$
47
$$$$
97
$$

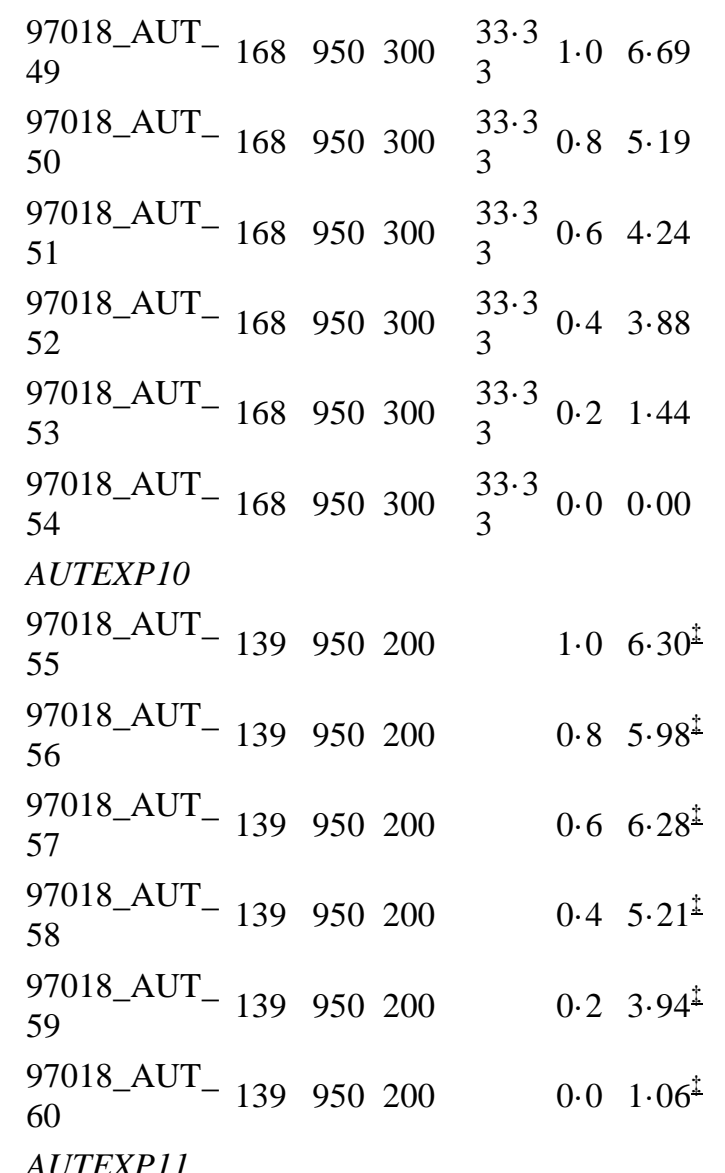 97018_AUT_ $139950 \quad 100 \quad 0.06$
61

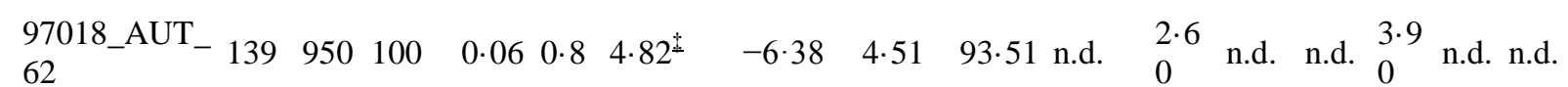 97018_AUT_ $139950 \quad 100 \quad 0.06 \quad 0.6$
63 97018 AUT $139 \quad 950 \quad 100 \quad 0.06 \quad 0.4 \quad 3 \cdot 2^{*}$




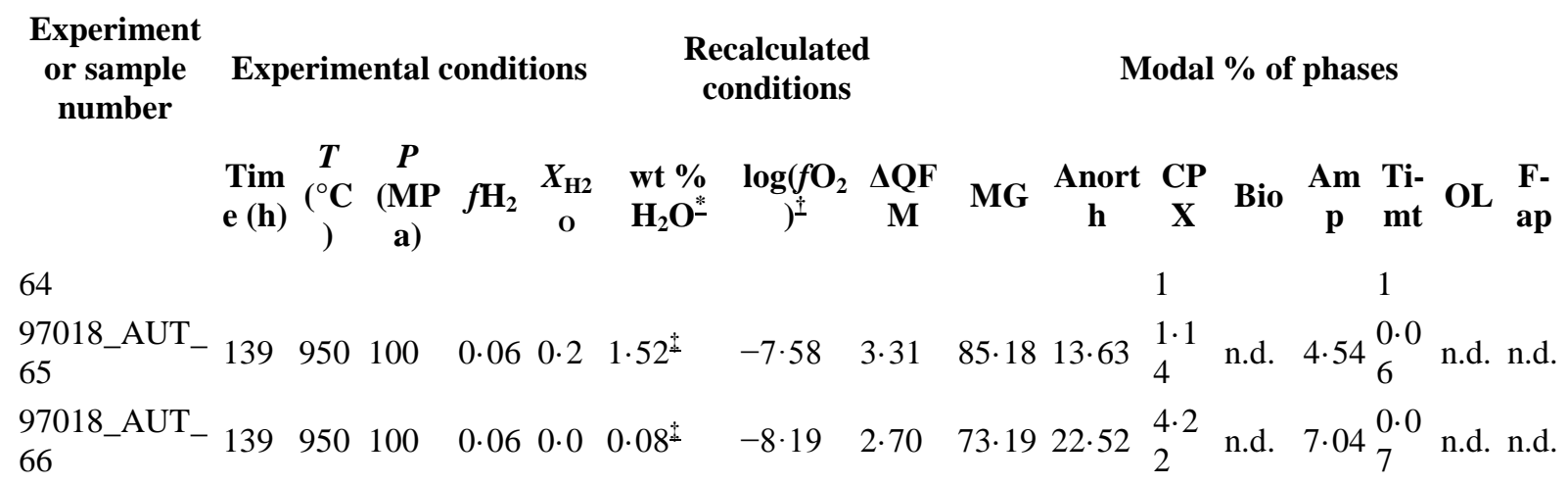

MG, matrix glass; Anorth, anorthoclase; CPX, clinopyroxene; Bio, biotite; Amph, amphibole; OL, olivine; Ti-mt, titanomagnetite; F-ap, fluorapatite; n.d., not detected.

*Wt $\% \mathrm{H}_{2} \mathrm{O}$ as determined by FTIR absorption spectroscopy on supra-liquidus charges (AUTEXP01 and 02) and by the by-difference calculation method for crystallized charges.

$\dagger \log \left(f \mathrm{O}_{2}\right)$ at water saturation determined from CoPd sensors following the procedure of Taylor et al. (1992). $\log \left(f \mathrm{O}_{2}\right)$ in single capsules recalculated based on $X_{\mathrm{H} 2 \mathrm{O}}$ initial except for the case $X_{\mathrm{H} 2 \mathrm{O}}=0$ for which an $X_{\mathrm{H} 2 \mathrm{O}}=0 \cdot 1$ value, more representative of the true initial amount of water, has been used.

$\$$ Recalculated values for charges where wt $\% \mathrm{H}_{2} \mathrm{O}$ as determined by the by-difference method yields an overestimate (above the $\mathrm{H}_{2} \mathrm{O}$ solubility curve). The wt $\% \mathrm{H}_{2} \mathrm{O}$ are recalculated based on the most hydrous charge wt $\% \mathrm{H}_{2} \mathrm{O}$ being equal to that predicted by the solubility curve.

At $100 \mathrm{MPa}$ and water-rich conditions, the liquidus is located between 975 and $950^{\circ} \mathrm{C}$ and is marked by the co-precipitation of clinopyroxene and titanomagnetite, both phases sharing the same liquidus curve. At low water contents $(<3 \mathrm{wt} \%)$, anorthoclase joins the stable assemblage between 975 and $1000^{\circ} \mathrm{C}$. Between 925 and $950^{\circ} \mathrm{C}$, and irrespective of water content, biotite crystallizes, displaying an essentially flat in-curve in the $T-X_{\mathrm{H} 2 \mathrm{O}}$ section. Amphibole appears within a similar temperature interval but is restricted to high water contents (>2 wt \%), crystallizing in all charges free of anorthoclase, suggesting limited overlap between the respective stability fields of these phases. Precipitation of amphibole in Erebus phonolites at $100 \mathrm{MPa}$ would imply both temperatures lower than $950^{\circ} \mathrm{C}$ and melt water contents higher than $2 \mathrm{wt} \%$ (Fig. 4a). In contrast to the proportions of clinopyroxene and titanomagnetite, which vary little over the $T-X_{\mathrm{H} 2 \mathrm{O}}$ space explored, the proportion of biotite increases with decreasing temperature and increasing water content, whereas that of feldspar increases with lower water content and lower temperature (Fig. 3). The natural modal abundance of feldspar (i.e. of the starting rock) is reproduced at a temperature close to $950^{\circ} \mathrm{C}$ and at water contents below $1 \mathrm{wt} \%$. Hence, a temperature of $950^{\circ} \mathrm{C}$ was used in the second series of polybaric experiments (Fig. 3b).

At pressures above $200 \mathrm{MPa}$ amphibole is present at $950^{\circ} \mathrm{C}$, showing that increasing pressure expands the thermal stability of amphibole in Na-phonolite magmas (Fig. 4c). Feldspar is stable throughout the range of pressures explored at low water contents. In the $P-X_{\mathrm{H} 2 \mathrm{O}}$ projection (Fig. $4 \mathrm{~b}$ and c), the anorthoclase liquidus curve has a vertical slope, although small inflections occur between 150 and $200 \mathrm{MPa}$. It is unclear whether this is real or results from 
error in water content determination. The natural proportion of feldspar is re-created in the pressure range 20 to $<200 \mathrm{MPa}$ and water contents below $1 \mathrm{wt} \%$ (Fig. $4 \mathrm{~b}$ and c). However, at pressures of $200 \mathrm{MPa}$ and above, crystallization of $30 \mathrm{wt} \%$ anorthoclase in Erebus phonolite necessarily occurs in the presence of amphibole (Fig. 4c). Fluorapatite was detected at a pressure of $200 \mathrm{MPa}$ and high water contents. Olivine is observed in experimental charges at pressures of 20, 200 and $300 \mathrm{MPa}$ and low water contents $(<2 \mathrm{wt} \%)$. The non-detection of olivine in charges at 50 and $100 \mathrm{MPa}$ is probably due to its low modal abundance $(<1 \%$ in run products) making it easy to overlook.

Six experimental charges at $950^{\circ} \mathrm{C}, 100 \mathrm{MPa}$ and over a range of $X_{\mathrm{H} 2 \mathrm{O}}$ were produced under highly oxidizing conditions $(\mathrm{NNO}+4)$ to assess the effect of $f \mathrm{O}_{2}$ on phase stabilities (97018_AUT_61 to 66). It should be noted that, owing to the decrease in $f \mathrm{H}_{2} \mathrm{O}$ (resulting from the increase in $\mathrm{CO}_{2}$ ) at constant $f \mathrm{H}_{2}$, the $f \mathrm{O}_{2}$ reached in the driest charges of the oxidized run is around $\mathrm{NNO}+2$ (Table 3). As shown in Fig. 5, the main difference compared with QFM conditions is that amphibole is stable together with feldspar at low water contents; that is, unlike the natural assemblage (Fig. 5). The decrease in feldspar abundance (and to a lesser extent of clinopyroxene, Table 3) in the oxidized charges relative to those at QFM (Fig. 5) suggests that amphibole crystallization proceeds at the expense of anorthoclase (and clinopyroxene), consistent with the limited overlap of the respective stability fields noted above. That an increase in $\mathrm{fO}_{2}$ increases the thermal stability of $\mathrm{Ca}$-amphibole has also been documented in metaluminous granite (Dall'Agnol et al., 1999).

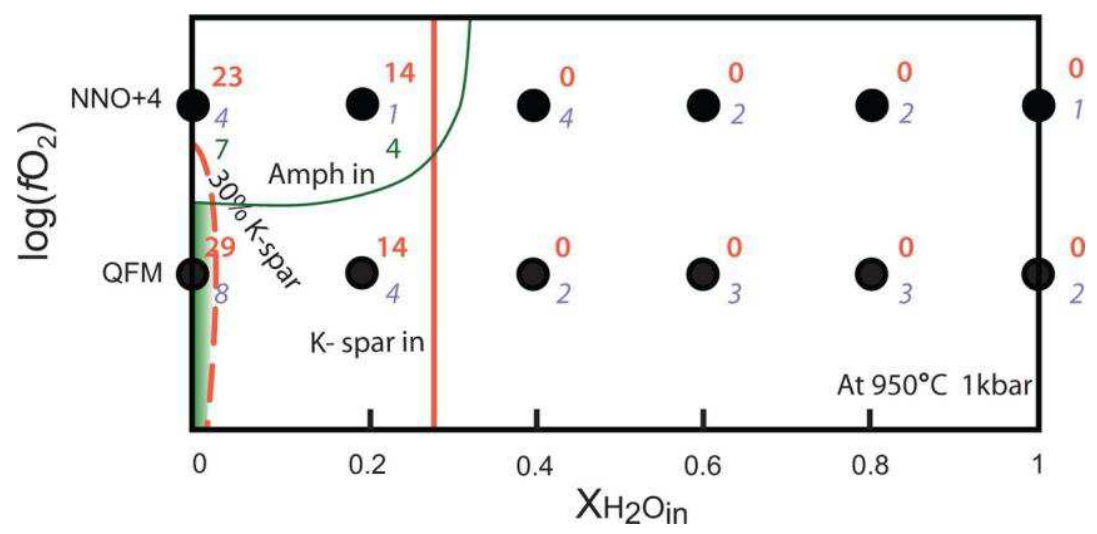

Fig. 5 : Phase relationship with varying $\log \left(f \mathrm{O}_{2}\right)$ and $X_{\mathrm{H} 2 \mathrm{Oin}}$ of Erebus phonolite at $100 \mathrm{MPa}$ and $950^{\circ} \mathrm{C}$. Filled black circles represent the $\log \left(f \mathrm{O}_{2}\right)-X_{\mathrm{H} 2 \mathrm{Oin}}$ location of single experimental charges. Phases lie inside their stability field and the proportion of each major phase is given for each experiment. The red dashed line marks $30 \%$ modal proportion of anorthoclase crystals in the run products. The shaded area shows the estimated stability conditions of $T-\mathrm{wt}$ $\% \mathrm{H}_{2} \mathrm{O}_{\text {fluid }}$ as inferred from the phenocryst assemblage of the Erebus phonolite. (See Figs 1 and 2 for abbreviations.)

\section{Phase compositions}

The small size of biotite, titanomagnetite and most of the clinopyroxene prevented the acquisition of good electron microprobe analyses. In some charges, however, clinopyroxene grains were large enough to be analysed and their composition is reported in Table 4 (low totals reflect the electron probe conditions: $2 \mathrm{nA}, 10 \mathrm{kV}$ and incomplete mobilization of $\mathrm{Si}$ ). The natural clinopyroxene composition ( $\mathrm{Wo}_{46} \mathrm{En}_{37} \mathrm{Fs}_{16}$ ) is most closely reproduced at $950^{\circ} \mathrm{C}$ and $20 \mathrm{MPa}$ (Table 4, Fig. 6). Although no clinopyroxene from charges lying within the 
stability domain inferred for the natural assemblage could be analysed, clinopyroxene in AUT23, which is very close to this stability window, shows very good agreement with the natural counterpart ( $\mathrm{Wo}_{49} \mathrm{En}_{36} \mathrm{Fs}_{16}$ ), and the $\mathrm{Fe} / \mathrm{Mg}$ partition coefficient with the liquid (Table 4).

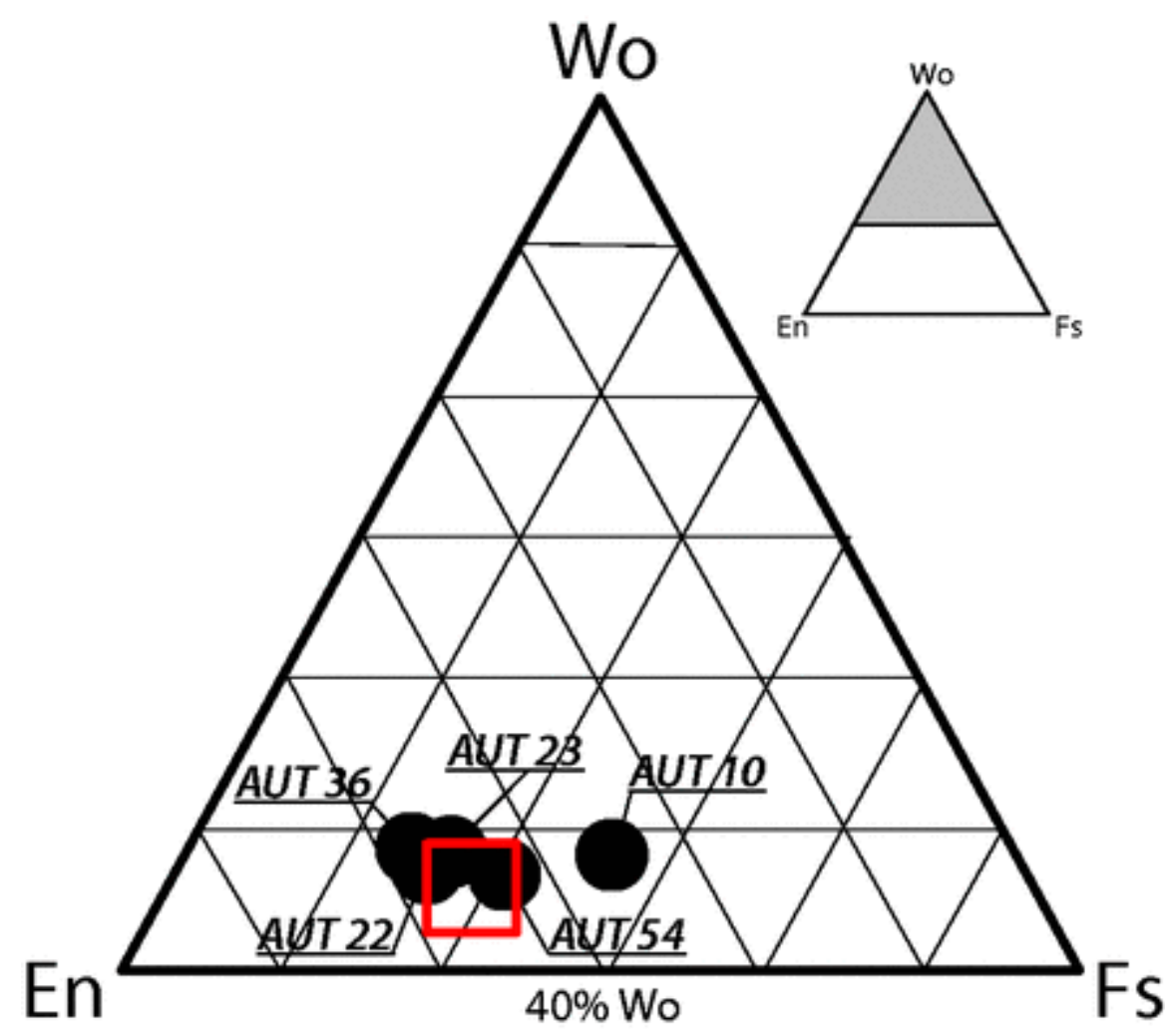

Fig. 6 : Ternary diagram of the chemical composition of pyroxene grains from pressurized experiments reported in Table 4. The end-members in the diagram are wollastonite (Wo; $\mathrm{Ca}_{2} \mathrm{Si}_{2} \mathrm{O}_{6}$ ), enstatite $\left(\mathrm{En} ; \mathrm{Mg}_{2} \mathrm{Si}_{2} \mathrm{O}_{6}\right)$ and ferrosilite $\left(\mathrm{Fs} ; \mathrm{Fe}_{2} \mathrm{SiO}_{6}\right.$ ). The rectangle shows the composition of the natural cpx for reference (Kelly et al., 2008b). It should be noted that the ternary diagram extends only to $40 \%$ Wo as shown by the shaded area in the upper right diagram. 

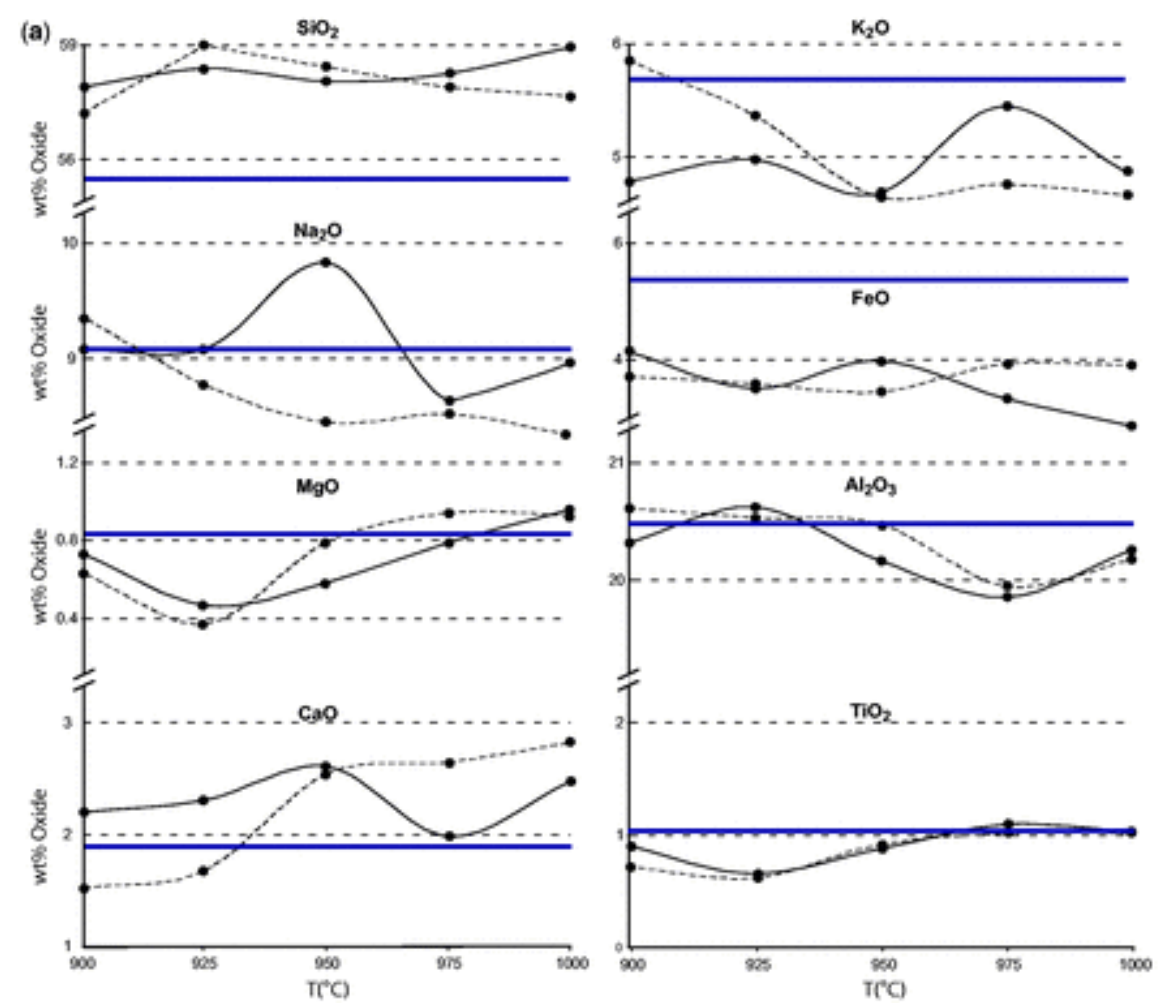

Fig. 7 : Connected scatter plots showing the evolution of the residual glass in term of eight major elements; $\mathrm{SiO}_{2}, \mathrm{Na}_{2} \mathrm{O}, \mathrm{MgO}, \mathrm{CaO}, \mathrm{K} 2 \mathrm{O}, \mathrm{FeO}, \mathrm{Al}_{2} \mathrm{O}_{3}, \mathrm{TiO}_{2}$ (from analyses recalculated to $100 \%$ ) (a) with temperature, at a pressure of $100 \mathrm{MPa}$ and $\log \left(f \mathrm{O}_{2}\right)$ near QFM, and (b) with pressure, at a temperature of $950^{\circ} \mathrm{C}$ and $\log \left(f \mathrm{O}_{2}\right)$ near QFM. Continuous lines represent charges at $X_{\mathrm{H} 2 \mathrm{Oin}}=0$; black dashed lines represent charges at $X_{\mathrm{H} 2 \mathrm{Oin}}=0 \cdot 2$. Bold horizontal lines represent the concentration of each element in the natural glass (Eschenbacher, 1998). 
Table 4 : Electron microprobe analyses of clinopyroxene from the experimental charges

\begin{tabular}{|c|c|c|c|c|c|c|c|c|c|c|c|}
\hline \multirow{3}{*}{$\begin{array}{c}\text { Experiment: } \\
n:\end{array}$} & \multirow{3}{*}{$\begin{array}{c}\begin{array}{c}\text { Natural } \\
\text { cpx }\end{array} \\
\\
19\end{array}$} & \multirow{2}{*}{\multicolumn{2}{|c|}{$\begin{array}{c}\text { AUTEXP03 } \\
(100 \mathrm{MPa} ; \\
\left.900^{\circ} \mathrm{C}\right) \\
\text { AUT10 }\left(X_{\mathrm{H} 2 \mathrm{O}}=\right. \\
0 \cdot 2)\end{array}$}} & \multirow{2}{*}{\multicolumn{2}{|c|}{$\begin{array}{l}\text { AUTEXP05 } \\
(100 \mathrm{MPa} \\
\left.975^{\circ} \mathrm{C}\right) \\
\text { AUT36 }\left(X_{\mathrm{H} 2 \mathrm{O}}\right. \\
=0)\end{array}$}} & \multicolumn{4}{|c|}{$\begin{array}{c}\text { AUTEXP07 } \\
\left(20 \mathrm{MPa} ; 950^{\circ} \mathrm{C}\right)\end{array}$} & \multirow{2}{*}{\multicolumn{2}{|c|}{$\begin{array}{l}\text { AUTEXP09 } \\
(300 \mathrm{MPa} \\
\left.950^{\circ} \mathrm{C}\right) \\
\left.{\text { AUT54 }\left(X_{\mathrm{H} 2 \mathrm{O}}\right.}=0\right)\end{array}$}} \\
\hline & & & & & & \multicolumn{2}{|c|}{$\begin{array}{c}\operatorname{AUT22}\left(X_{\mathrm{H} 2 \mathrm{O}}\right. \\
=0.4)\end{array}$} & \multicolumn{2}{|c|}{$\begin{array}{c}\operatorname{AUT23}\left(X_{\mathrm{H} 2 \mathrm{O}}\right. \\
=0 \cdot 2)\end{array}$} & & \\
\hline & & 3 & SD & 3 & SD & 2 & SD & 2 & SD & 6 & SD \\
\hline $\mathrm{SiO}_{2}$ & $50 \cdot 89$ & 48.01 & $1 \cdot 02$ & $48 \cdot 43$ & 1.94 & 49.00 & $1 \cdot 29$ & $48 \cdot 14$ & $0 \cdot 41$ & $48 \cdot 96$ & $1 \cdot 01$ \\
\hline $\mathrm{TiO}_{2}$ & $1 \cdot 35$ & 1.43 & 0.38 & 1.71 & $0 \cdot 18$ & $1 \cdot 51$ & 0.60 & 1.09 & $0 \cdot 16$ & 1.49 & $0 \cdot 31$ \\
\hline $\mathrm{Al}_{2} \mathrm{O}_{3}$ & $2 \cdot 81$ & 5.95 & 1.90 & $5 \cdot 06$ & $2 \cdot 31$ & $3 \cdot 04$ & $1 \cdot 21$ & $2 \cdot 52$ & $0 \cdot 34$ & 3.05 & 0.79 \\
\hline $\mathrm{FeO}$ & $9 \cdot 54$ & $12 \cdot 68$ & 0.65 & $6 \cdot 52$ & $0 \cdot 22$ & 8.01 & 0.09 & $8 \cdot 85$ & $0 \cdot 28$ & $11 \cdot 55$ & 1.06 \\
\hline $\mathrm{MnO}$ & 0.65 & 0.83 & 0.27 & 0.63 & 0.08 & 0.80 & $0 \cdot 11$ & 0.64 & 0.02 & 0.82 & $0 \cdot 26$ \\
\hline $\mathrm{MgO}$ & $12 \cdot 23$ & $7 \cdot 07$ & 0.87 & $10 \cdot 80$ & $1 \cdot 16$ & 11.65 & 0.87 & 11.49 & $0 \cdot 17$ & $10 \cdot 39$ & 0.52 \\
\hline $\mathrm{CaO}$ & $21 \cdot 13$ & 18.60 & $2 \cdot 22$ & $19 \cdot 38$ & 1.69 & $20 \cdot 45$ & 0.77 & 21.74 & $0 \cdot 36$ & $20 \cdot 78$ & $1 \cdot 04$ \\
\hline $\mathrm{Na}_{2} \mathrm{O}$ & 0.93 & 1.68 & $0 \cdot 30$ & $1 \cdot 32$ & 0.68 & 1.00 & $0 \cdot 32$ & $0 \cdot 89$ & $0 \cdot 01$ & 1.09 & $0 \cdot 15$ \\
\hline $\mathrm{K}_{2} \mathrm{O}$ & & 0.50 & $0 \cdot 31$ & $0 \cdot 21$ & $0 \cdot 14$ & $0 \cdot 19$ & $0 \cdot 16$ & $0 \cdot 19$ & $0 \cdot 12$ & $0 \cdot 11$ & 0.07 \\
\hline Total & $99 \cdot 53$ & $96 \cdot 73$ & 0.58 & 94.07 & 2.09 & 95.64 & 0.66 & 95.56 & $1 \cdot 12$ & $98 \cdot 24$ & 0.91 \\
\hline $\mathrm{Fe}_{\mathrm{T}} / \mathrm{Mg}$ & $0 \cdot 44$ & $1 \cdot 01$ & & $0 \cdot 34$ & & 0.39 & & $0 \cdot 43$ & & 0.62 & \\
\hline $\mathrm{Fe}_{\mathrm{T}} /\left(\mathrm{Fe}_{\mathrm{T}}+\mathrm{Mg}\right)$ & $0 \cdot 30$ & 0.50 & & $0 \cdot 25$ & & $0 \cdot 28$ & & $0 \cdot 30$ & & $0 \cdot 38$ & \\
\hline $\mathrm{Fe}_{2} /\left(\mathrm{Fe}_{2}+\mathrm{Mg}\right)$ & $0 \cdot 27$ & 0.50 & & $0 \cdot 25$ & & 0.27 & & $0 \cdot 21$ & & $0 \cdot 32$ & \\
\hline Wo & $46 \cdot 34$ & $48 \cdot 50$ & & $49 \cdot 07$ & & 47.65 & & $48 \cdot 71$ & & $46 \cdot 95$ & \\
\hline En & $37 \cdot 32$ & $25 \cdot 67$ & & 38.03 & & 37.78 & & $35 \cdot 81$ & & $32 \cdot 68$ & \\
\hline Fs & $16 \cdot 33$ & $25 \cdot 82$ & & $12 \cdot 89$ & & $14 \cdot 57$ & & $15 \cdot 48$ & & $20 \cdot 38$ & \\
\hline $\mathrm{Fe}_{\mathrm{T}} / \mathrm{Mg}$ in glass & $3 \cdot 62$ & $3 \cdot 31$ & & $2 \cdot 37$ & & 3.78 & & $3 \cdot 36$ & & $4 \cdot 72$ & \\
\hline $\begin{array}{l}K_{\mathrm{d}}(\mathrm{Fe} / \mathrm{Mg} \mathrm{CPX}- \\
\text { Melt })\end{array}$ & $0 \cdot 12$ & $0 \cdot 30$ & & $0 \cdot 14$ & & $0 \cdot 10$ & & $0 \cdot 13$ & & $0 \cdot 13$ & \\
\hline
\end{tabular}

- The composition of the natural cpx (Kelly et al., 2008b) is given for reference. The $\mathrm{Fe} / \mathrm{Mg}$ ratio, $\mathrm{Fe}$ and $\mathrm{Fe}^{2+}$ numbers are given together with the partition coefficient $\left(K_{\mathrm{d}}\right)$ for the $\mathrm{Fe} / \mathrm{Mg}$ ratio between $\mathrm{cpx}$ and liquid. Clinopyroxene endmembers are wollastonite $\left(\mathrm{Wo} ; \mathrm{Ca}_{2} \mathrm{Si}_{2} \mathrm{O}_{6}\right)$, enstatite $\left(\mathrm{En} ; \mathrm{Mg}_{2} \mathrm{Si}_{2} \mathrm{O}_{6}\right)$ and ferrosilite $\left(\mathrm{Fs} ; \mathrm{Fe}_{2} \mathrm{SiO}_{6}\right)$.

Fluorapatite composition could not be measured accurately because of the small size of crystals and groundmass contamination; fluorine was nevertheless abundant in all analysed apatite. Amphibole is present mostly as kaersutite or ferropargasite in the cooler experiments. Compositions are reported in Table 5, and are characterized by elevated $\mathrm{Ti}$ and $\mathrm{K}$ contents. Their Al content does not seem to vary significantly with pressure, contrary to what is found for other intermediate to silicic magmas (e.g. Prouteau \& Scaillet, 2003). Olivine compositions in the experimental charges are reported in Table 6 (note that the slightly elevated $\mathrm{Al}_{2} \mathrm{O}_{3}$ content in some olivine grains is probably due to contamination of the analysis by surrounding glass) and ranges between $\mathrm{Fo}_{49}$ and $\mathrm{Fo}_{53}$ at 20 and $200 \mathrm{MPa}$ [i.e. close to the natural olivine $\left.\left(\mathrm{Fo}_{50}\right)\right]$, whereas that produced at $300 \mathrm{MPa}$ has a significantly lower Fo content $\left(\mathrm{Fo}_{39}\right)$. Feldspars in the experimental charges are all anorthoclase with $\mathrm{Ab}$ contents between 
61 and 67\%, An contents between 6 and 22\%, and Or contents between 33 and 12\%. Natural anorthoclase crystals show significant zonation and a detailed comparison with the experimental products will be investigated in a future study. To a first order, however, the bulk composition of the natural anorthoclase is most closely reproduced in high-pressure experiments at $950^{\circ} \mathrm{C}$, and in $0 \cdot 1 \mathrm{MPa}$ experiments at $975^{\circ} \mathrm{C}$.

Table 5 : Amphibole compositions (wt \%) obtained by electron microprobe analysis (in wt \% oxide)

AUTEXP03

$\left(100 \mathrm{MPa} ; 900^{\circ} \mathrm{C}\right)$
AUTEXP06

$\left(100 \mathrm{MPa} ; 9^{\circ} \mathrm{C}\right)$
AUTEXP0 AUTEXP1 9

(300 MPa; (200 MPa; $\left.\left.950^{\circ} \mathrm{C}\right) \quad 950^{\circ} \mathrm{C}\right)$

$\begin{array}{lllllllll}\text { Experiment AUT06 AUT07 } & \text { AUT08 } & \text { AUT37 } & \text { AUT38 } & \text { AUT39 } & \text { AUT53 } & \text { AUT59 }\end{array}$

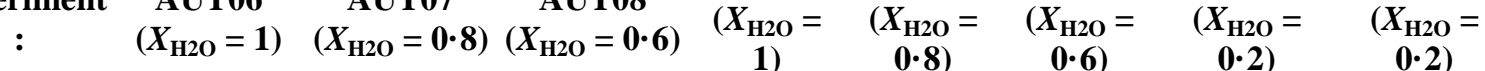

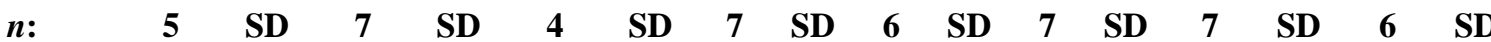
$\begin{array}{llllllllllllllllllll}\mathrm{SiO}_{2} & 38.34 & 0.43 & 37.62 & 0.34 & 38 \cdot 24 & 0.49 & 40 \cdot 2 & 0 \cdot 6 & 40 \cdot 0 & 0.6 & 39 \cdot 3 & 0.4 & 40 \cdot 19 & 0 \cdot 86 & 39 \cdot 80 & 0.69\end{array}$

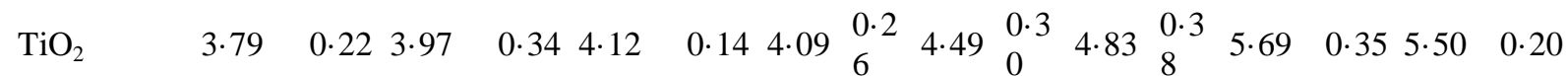
$\begin{array}{llllllllllllllllll}\mathrm{Al}_{2} \mathrm{O}_{3} & 11.19 & 0.54 & 11 \cdot 14 & 0.43 & 10.67 & 0.17 & 11.2 & 0.4 & 11 \cdot 3 & 0.5 & 11.4 & 0.4 & 11.06 & 0.29 & 11.44 & 0.38\end{array}$ $\begin{array}{lllllllllllllllllll}\mathrm{FeO} & 17 \cdot 26 & 0.71 & 16 \cdot 56 & 0.60 & 16 \cdot 54 & 0.40 & 15 \cdot 4 & 0 \cdot 3 & 15 \cdot 5 & 0 \cdot 5 & 15 \cdot 7 & 0.4 & 14 \cdot 83 & 0.74 & 13 \cdot 28 & 0.41\end{array}$ $\begin{array}{llllllllllllllllll}\mathrm{MnO} & 0.63 & 0.08 & 0.63 & 0.17 & 0.62 & 0.03 & 0.50 & \begin{array}{l}0.1 \\ 6\end{array} & 0.61 & 0.1 & 0.46 & \begin{array}{l}0.1 \\ 9\end{array} & 0.52 & 0.18 & 0.48 & 0.05\end{array}$

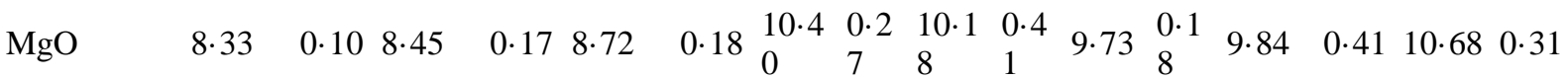

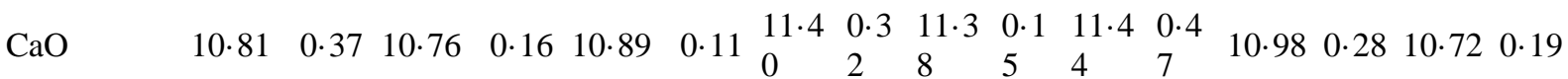
$\begin{array}{llllllllllllllllll}\mathrm{Na}_{2} \mathrm{O} & 2.67 & 0.10 & 2.64 & 0.08 & 2.76 & 0.04 & 2.75 & \begin{array}{l}0.0 \\ 9\end{array} & 2.82 & 0.0 & 2.71 & 0.0 & 2.79 & 0.09 & 2.78 & 0.12\end{array}$ $\begin{array}{lllllllllllllllll}\mathrm{K}_{2} \mathrm{O} & 1.28 & 0.09 & 1.24 & 0.12 & 1.16 & 0.11 & 1.27 & 0.1 & 1.29 & \begin{array}{l}0.1 \\ 3\end{array} & 1.28 & \begin{array}{l}0.0 \\ 8\end{array} & 1.33 & 0.09 & 1 \cdot 18 & 0.07\end{array}$ $\begin{array}{lllllllllllllllllll}\text { Total } & 94.29 & 1.83 & 93.02 & 1.32 & 93.71 & 1.34 & 97.3 & 0.9 & 97.6 & 0.7 & 96.9 & 1.2 & 97.22 & 1.47 & 95.98 & 0.64\end{array}$ $\begin{array}{cccccc} & \text { Potassian } & \text { Potassian } & \text { Titnanian } & \text { Potassian } & \text { Potassian } \\ \text { titanian } & \text { titanian } & & \text { Kaersutite Kaersutite } & & \\ \text { Name } & \text { ferropargasit ferropargasit ferropargasit } & \text { e } & \text { e } & \text { Kaersutite } & \text { kaersutite }\end{array}$ 
Table 6 : Electron microprobe analyses of olivine from the experimental charges

\begin{tabular}{|c|c|c|c|c|c|c|}
\hline \multirow[t]{2}{*}{ Nat ol ${ }^{*}$} & \multicolumn{3}{|c|}{$\begin{array}{c}\text { AUTEXP07 } \\
\left(20 \text { MPa; } 950^{\circ} \mathrm{C}\right)\end{array}$} & \multicolumn{2}{|c|}{$\begin{array}{c}\text { AUTEXP09 } \\
\left(300 \mathrm{MPa} ; 9^{\circ}{ }^{\circ} \mathrm{C}\right)\end{array}$} & \multirow{2}{*}{$\begin{array}{c}\text { AUTEXP10 } \\
\left(200 \mathrm{MPa} ; 950^{\circ} \mathrm{C}\right) \\
\text { AUT60 }\left(X_{\mathrm{H} 20}=0 \cdot 2\right)\end{array}$} \\
\hline & $\operatorname{AUT23}\left(X_{\mathrm{H} 2 \mathrm{O}}=0 \cdot 2\right)$ & AUT24 & $\left.Y_{\mathrm{H} 2 \mathrm{O}}=0\right)$ & AUT5 & $\left.\mathrm{K}_{\mathrm{H} 2 \mathrm{O}}=0\right)$ & \\
\hline 67 & 1 & 2 & SD & 6 & SD & 1 \\
\hline \multirow[t]{2}{*}{$34 \cdot 80$} & $34 \cdot 21$ & $34 \cdot 39$ & 0.63 & $32 \cdot 62$ & 0.95 & $33 \cdot 87$ \\
\hline & $0 \cdot 17$ & $0 \cdot 09$ & $0 \cdot 01$ & $0 \cdot 36$ & 0.62 & $0 \cdot 40$ \\
\hline $0 \cdot 01$ & $0 \cdot 08$ & $0 \cdot 60$ & 0.69 & $0 \cdot 06$ & $0 \cdot 05$ & $1 \cdot 20$ \\
\hline $38 \cdot 33$ & $35 \cdot 39$ & $33 \cdot 61$ & $0 \cdot 27$ & $44 \cdot 83$ & $0 \cdot 71$ & $36 \cdot 50$ \\
\hline $2 \cdot 45$ & $3 \cdot 08$ & $2 \cdot 60$ & $0 \cdot 27$ & $2 \cdot 62$ & $0 \cdot 17$ & $2 \cdot 27$ \\
\hline $23 \cdot 53$ & $23 \cdot 19$ & $23 \cdot 05$ & $0 \cdot 82$ & $17 \cdot 86$ & 1.09 & $21 \cdot 67$ \\
\hline \multirow[t]{2}{*}{$0 \cdot 50$} & $0 \cdot 43$ & $0 \cdot 48$ & $0 \cdot 06$ & $0 \cdot 71$ & $0 \cdot 28$ & 0.54 \\
\hline & $0 \cdot 00$ & $0 \cdot 22$ & $0 \cdot 19$ & $0 \cdot 05$ & $0 \cdot 05$ & $0 \cdot 21$ \\
\hline $99 \cdot 62$ & $96 \cdot 57$ & $95 \cdot 34$ & $0 \cdot 48$ & $99 \cdot 17$ & $2 \cdot 14$ & $97 \cdot 47$ \\
\hline $50 \cdot 30$ & $51 \cdot 42$ & $52 \cdot 71$ & & $39 \cdot 68$ & & $49 \cdot 45$ \\
\hline $45 \cdot 96$ & $44 \cdot 02$ & $43 \cdot 13$ & & $55 \cdot 87$ & & $46 \cdot 72$ \\
\hline 2.98 & 3.88 & $3 \cdot 37$ & & $3 \cdot 31$ & & 2.94 \\
\hline 0.77 & 0.68 & 0.78 & & $1 \cdot 14$ & & $0 \cdot 88$ \\
\hline
\end{tabular}

- *The composition of the natural olivine (Kelly et al., 2008b) is given for reference. Olivine endmembers are tephroite $\left(\mathrm{Te} ; \mathrm{Mn}_{2} \mathrm{SiO}_{4}\right)$, forsterite $\left(\mathrm{Fo} ; \mathrm{Mg}_{2} \mathrm{SiO}_{4}\right)$, fayalite $\left(\mathrm{Fa} ; \mathrm{Fe}_{2} \mathrm{SiO}_{4}\right)$ and $\mathrm{Ca}$-rich olivine $(\mathrm{Ca}-\mathrm{Ol})$. 
Table 7 : Electron microprobe analyses of glasses from all the experimental charges

$\begin{array}{cccc}\text { AUTEXP01 } & \text { AUTEXP02 } & \text { AUTEXP03 } & \text { AUTEXP04 } \\ \left(100 \mathrm{MPa} ; \mathbf{1 0 0 0}^{\circ} \mathrm{C}\right) & \left(50 \mathrm{MPa} ; \mathbf{1 0 0 0}^{\circ} \mathrm{C}\right) & \left(100 \mathrm{MPa} ; \mathbf{9 0 0}^{\circ} \mathrm{C}\right) & \left(100 \mathrm{MPa} ; \mathbf{9 5 0}^{\circ} \mathrm{C}\right)\end{array}$

$\begin{array}{llllllllllllllllllllllllll}\mathbf{E x} & \mathbf{A U} & \mathbf{A U} & \mathbf{A U} & \mathbf{A U} & \mathbf{A U} & \mathbf{A U} & \mathbf{A U} & \mathbf{A U} & \mathbf{A U} & \mathbf{A U} & \mathbf{A U} & \mathbf{A U} & \mathbf{A U} & \mathbf{A U} & \mathbf{A U} & \mathbf{A U} & \mathbf{A U} & \mathbf{A U} & \mathbf{A U} & \mathbf{A U} & \mathbf{A U} & \mathbf{A U} & \mathbf{A U} & \mathbf{A U}\end{array}$

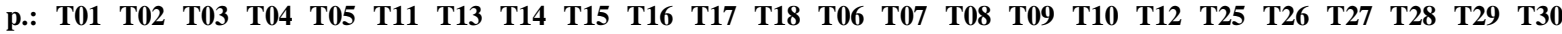
$\begin{array}{lllllllllllllllllllllllllllllllll}n: & 10 & 10 & 8 & 9 & 10 & 10 & 8 & 7 & 9 & 7 & 10 & 10 & 5 & 6 & 5 & 5 & 5 & 6 & 7 & 7 & 7 & 7 & 7 & 6\end{array}$ $\begin{array}{lllllllllllllllllllllllllll}\mathrm{Si} & 56 \cdot 0 & 56 \cdot 4 & 55 \cdot 4 & 56 \cdot 4 & 56 \cdot 7 & 58 \cdot 1 & 57 \cdot 0 & 56 \cdot 9 & 57 \cdot 1 & 57 \cdot 2 & 57 \cdot 7 & 58 \cdot 0 & 57 \cdot 1 & 57 \cdot 1 & 57 \cdot 5 & 56 \cdot 6 & 56 \cdot 0 & 58 \cdot 4 & 56 \cdot 4 & 56 \cdot 5 & 57 \cdot 2 & 56 \cdot 6 & 57 \cdot 7 & 58 \cdot 5\end{array}$ $\begin{array}{llllllllllllllllllllllllll}\mathrm{O}_{2} & 8 & 2 & 2 & 9 & 7 & 4 & 7 & 9 & 0 & 0 & 5 & 2 & 9 & 0 & 6 & 2 & 7 & 1 & 1 & 8 & 8 & 9 & 4 & 2\end{array}$

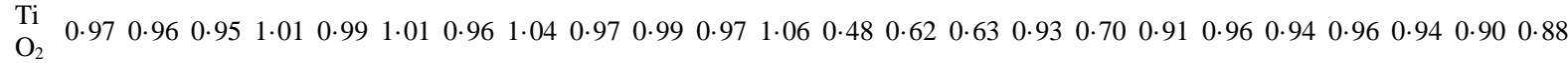

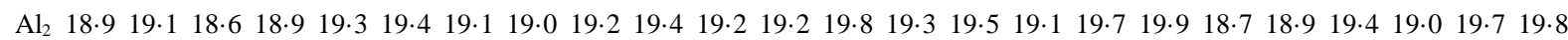
$\begin{array}{llllllllllllllllllllllllll}\mathrm{O}_{3} & 8 & 6 & 3 & 9 & 7 & 9 & 6 & 3 & 4 & 3 & 7 & 4 & 3 & 3 & 2 & 0 & 0 & 9 & 1 & 0 & 3 & 4 & 5 & 2\end{array}$

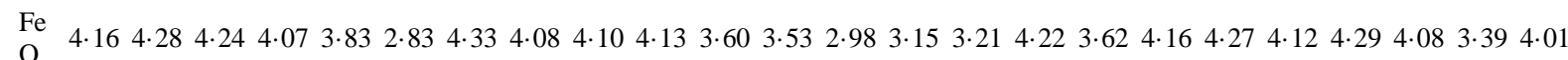

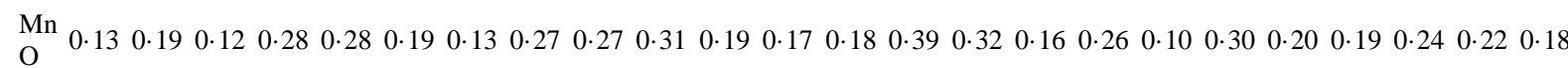

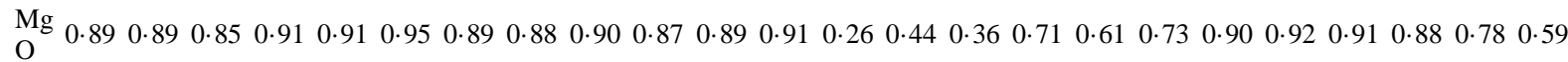

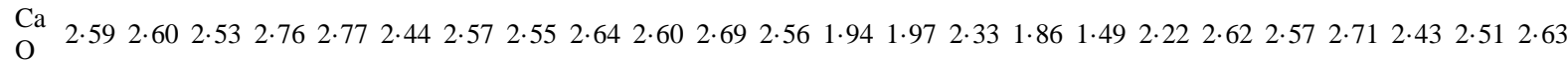

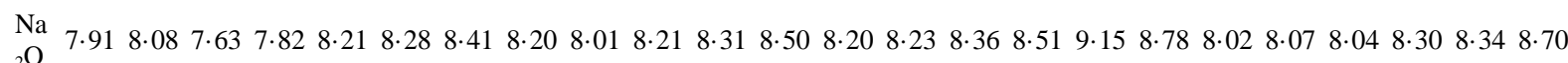

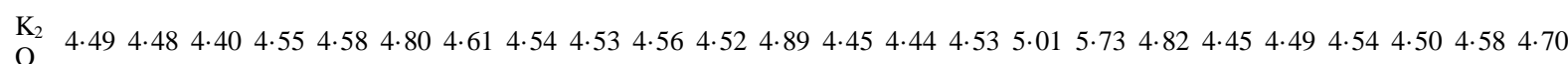

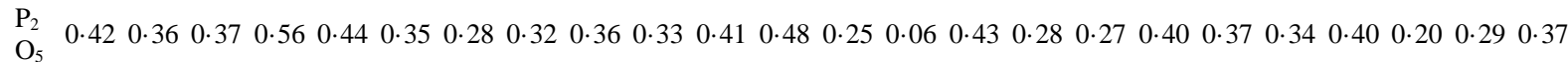

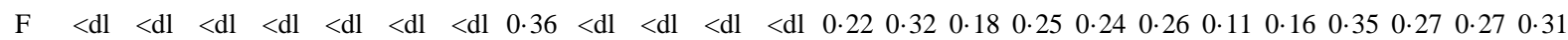

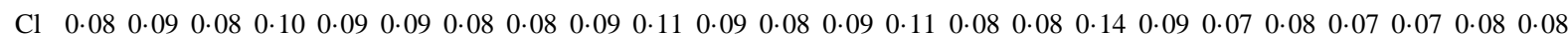

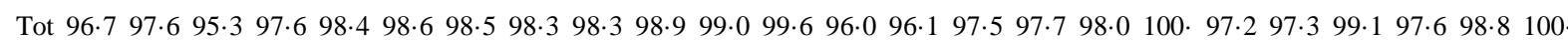
$\begin{array}{llllllllllllllllllllllllll}\text { al } & 6 & 1 & 6 & 3 & 7 & 8 & 3 & 3 & 7 & 5 & 3 & 1 & 9 & 5 & 3 & 2 & 0 & 87 & 0 & 5 & 6 & 4 & 6 & 79\end{array}$

\begin{tabular}{|c|c|c|c|}
\hline $\begin{array}{c}\text { AUTEXP05 } \\
\left(100 \mathrm{MPa} \cdot 975^{\circ} \mathrm{C}\right.\end{array}$ & $\begin{array}{c}\text { AUTEXP06 } \\
\text { (100 }\end{array}$ & $\begin{array}{c}\text { AUTEXP07 } \\
\end{array}$ & $\begin{array}{c}\text { AUTEXP08 } \\
\left.\text { (50 MPa. } 950^{\circ} \mathrm{C}\right)\end{array}$ \\
\hline
\end{tabular}

$\begin{array}{lllllllllllllllllllllll}\text { Ex AU AU } & A U & A U & A U & A U & A U & A U & A U & A U & A U & A U & A U & A U & A U & A U & A U & A U & A U & A U & A U & A U & A U & A U\end{array}$

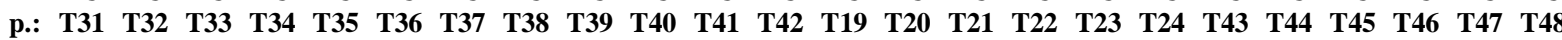
$\begin{array}{lllllllllllllllllllllllllllll}n: & 7 & 7 & 7 & 6 & 7 & 7 & 7 & 7 & 7 & 7 & 7 & 7 & 7 & 7 & 7 & 6 & 6 & 7 & 5 & 5 & 5 & 6 & 7 & 6\end{array}$

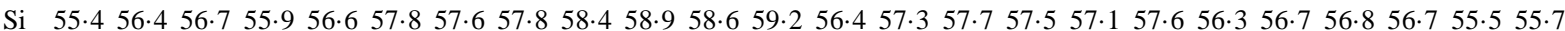

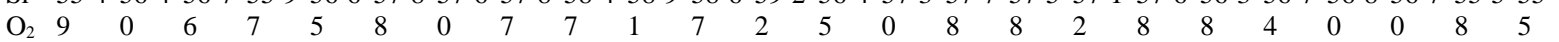

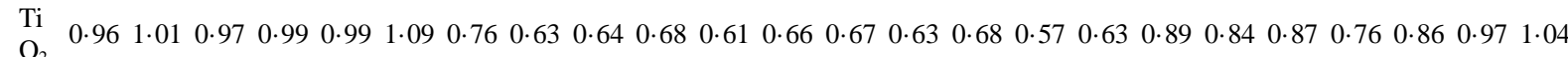

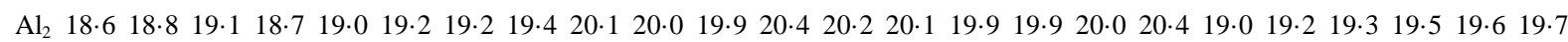
$\begin{array}{lllllllllllllllllllllllll}\mathrm{O}_{3} & 6 & 6 & 8 & 0 & 3 & 4 & 7 & 5 & 0 & 2 & 3 & 2 & 1 & 3 & 5 & 9 & 8 & 7 & 7 & 7 & 5 & 8 & 9 & 4\end{array}$

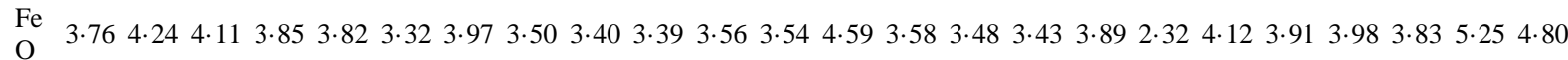

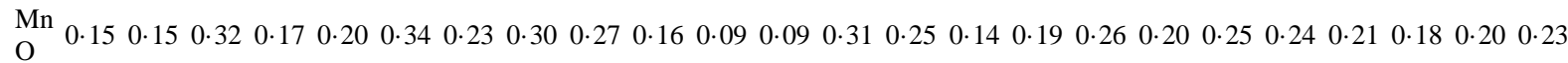

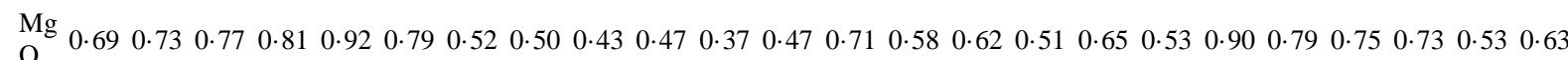
$\begin{array}{lllllllllllllllllllllllllllllllllll}\mathrm{Ca} & 2.96 & 2.83 & 2.76 & 2.70 & 2.59 & 1.97 & 2.08 & 2.20 & 2.00 & 1.85 & 1.67 & 2.34 & 1.02 & 1.51 & 1.36 & 1.16 & 1.36 & 1.09 & 2.38 & 2.15 & 2.18 & 2.07 & 1.48 & 1.49\end{array}$ ${ }_{2}^{\mathrm{Na}} \begin{aligned} & \mathrm{O} \\ & \mathrm{N}\end{aligned}$

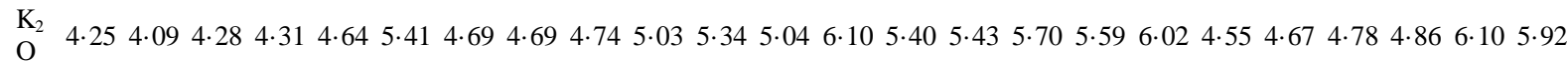

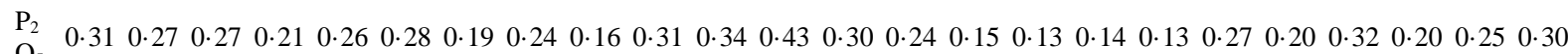
$\begin{array}{lllllllllllllllll}\text { F } \quad & 0.13 & 0.13 & 0.08 & 0.22 & 0.34 & 0.23 & 0.18 & 0.33 & 0.20 & 0.20 & 0.09 & 0.24\end{array}$ $\begin{array}{llllllllllllllllll}\mathrm{Cl} & 0.09 & 0.08 & 0.10 & 0.09 & 0.08 & 0.08 & 0.07 & 0.08 & 0.07 & 0.08 & 0.11 & 0.10\end{array}$ Tot $96.096 .697 .796 .697 .899 .3 \quad 97.798 .0 \quad 98.699 .6 \quad 99.4 \quad 101.99 .798 .198 .097 .998 .598 .296 .596 .997 .397 .099 .399 .7$ $\begin{array}{llllllllllllllllllllllllll}\text { al } & 9 & 4 & 3 & 0 & 7 & 8 & 1 & 2 & 7 & 1 & 9 & 43 & 4 & 6 & 6 & 4 & 9 & 7 & 6 & 2 & 7 & 8 & 4 & 0\end{array}$ 


\section{AUTEXP09 \\ AUTEXP10 \\ AUTEXP11 \\ C_ATM (0·1 MPa) \\ $\left(300 \mathrm{MPa} ; 950^{\circ} \mathrm{C}\right)$ \\ (200 MPa; $\left.950^{\circ} \mathrm{C}\right)$ \\ (100 MPa; $950^{\circ} \mathrm{C}$; oxidized)

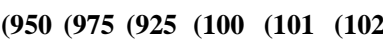 \\ $\left.\left.\left.\left.\left.{ }^{\circ} \mathrm{C}\right) \quad{ }^{\circ} \mathrm{C}\right){ }^{\circ} \mathrm{C}\right)\left(0^{\circ} \mathrm{C}\right) 8^{\circ} \mathrm{C}\right) 5^{\circ} \mathrm{C}\right)$}

Nat

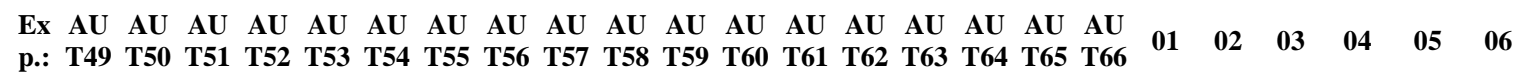
$\begin{array}{lllllllllllllllllllllllllll}n: & 7 & 7 & 7 & 7 & 7 & 6 & 10 & 10 & 9 & 7 & 7 & 10 & 7 & 7 & 7 & 7 & 7 & 7 & 10 & 10 & 10 & 10 & 7 & 4 & 18\end{array}$

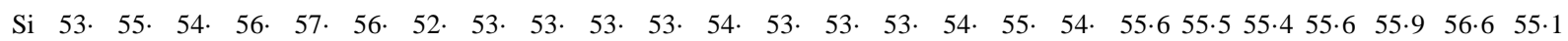
$\begin{array}{llllllllllllllllllllllllll}\mathrm{O}_{2} & 71 & 02 & 81 & 00 & 05 & 84 & 86 & 17 & 00 & 19 & 79 & 08 & 16 & 87 & 95 & 76 & 56 & 01 & 2 & 6 & 4 & 9 & 0 & 8 & 1\end{array}$

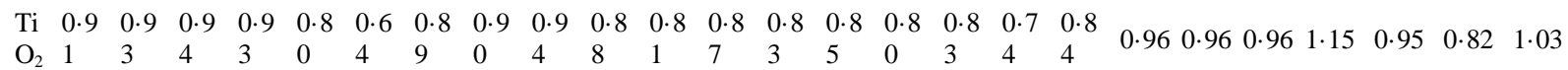
$\begin{array}{lllllllllllllllllllllllllllll}\mathrm{Al}_{2} & 18 & 19 & 19 & 19 & 19 & 19 & 20 & 18 & 18 & 18 & 18 & 19 & 19 & 18 & 18 & 18 & 19 & 19 & 19 & 19.4 & 19 \cdot 2 & 19 \cdot 3 & 18.9 & 19.7 & 19.9 & 19 \cdot 8\end{array}$

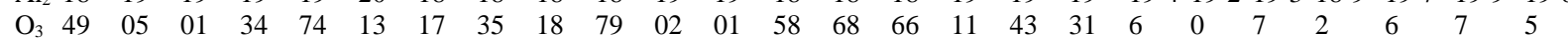

$\begin{array}{lllllllllllllllllllllllllllllll}\mathrm{Fe} & 3 \cdot 8 & 3 \cdot 7 & 4 \cdot 0 & 3 \cdot 1 & 3 \cdot 2 & 4 \cdot 0 & 4 \cdot 3 & 4 \cdot 1 & 4 \cdot 0 & 4 \cdot 2 & 3 \cdot 9 & 4 \cdot 2 & 3 \cdot 1 & 2 \cdot 6 & 2 \cdot 6 & 2 \cdot 5 & 2 \cdot 4 & 3 \cdot 7 & 4.87 & 5.40 & 5.09 & 5 \cdot 57 & 4.53 & 3.72 & 5 \cdot 34\end{array}$

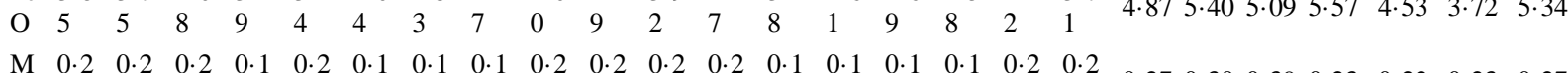
$\begin{array}{llllllllllllllllllllllllllllll}\mathrm{nO} & 0 & 1 & 0 & 6 & 4 & 9 & 9 & 8 & 1 & 3 & 2 & 6 & 7 & 0 & 8 & 1 & 0 & 3 & 0.27 & 0.30 & 0.39 & 0.23 & 0.22 & 0.23 & 0.27\end{array}$ $\begin{array}{lllllllllllllllllllllllllllllll}\text { M } & 0.8 & 0.8 & 0.8 & 0.8 & 0.6 & 0.5 & 0.8 & 0.8 & 0.8 & 0.7 & 0.7 & 0.8 & 0.7 & 0.7 & 0.7 & 0.7 & 0.5 & 0.7 & 0.82 & 0.87 & 0.93 & 0.98 & 0.86 & 0.68 & 0.83\end{array}$

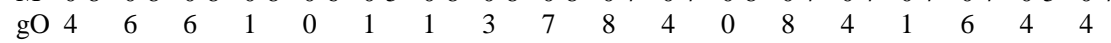

$\begin{array}{llllllllllllllllllllllllllllllllll}\mathrm{Ca} & 2.3 & 2.4 & 2.3 & 2.4 & 1.9 & 1.8 & 2.4 & 2.3 & 2.5 & 2.3 & 2.3 & 2.0 & 2.5 & 2.3 & 2.4 & 2.4 & 1.7 & 1.7 & 1.13 & 1.95 & 1.31 & 2.12 & 1.06 & 0.58 & 1.88\end{array}$ $\begin{array}{lllllllllllllllllllllllllllll}\mathrm{O} & 7 & 0 & 6 & 7 & 1 & 6 & 0 & 8 & 3 & 4 & 0 & 9 & 2 & 2 & 9 & 2 & 8 & 4 & 1.13 & 1.95 & 1.31 & 2.12 & 1.06 & 0.58 & 1.88\end{array}$ $\begin{array}{llllllllllllllllllllllllllllll}\mathrm{Na} & 7 \cdot 1 & 6.8 & 7.4 & 7 \cdot 2 & 8.0 & 8.8 & 7.3 & 7.6 & 7.7 & 8.1 & 8.2 & 8.7 & 7.7 & 7.7 & 7.8 & 8.1 & 8.6 & 9.0 & 8.97 & 8.56 & 9.38 & 8.32 & 8.30 & 8.17 & 9.07\end{array}$

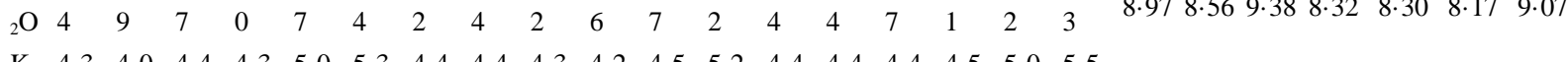
$\begin{array}{llllllllllllllllllllllllll}\mathrm{K}_{2} & 4 \cdot 3 & 4 \cdot 0 & 4 \cdot 4 & 4 \cdot 3 & 5 \cdot 0 & 5 \cdot 3 & 4 \cdot 4 & 4 \cdot 4 & 4 \cdot 3 & 4 \cdot 2 & 4 \cdot 5 & 5 \cdot 2 & 4 \cdot 4 & 4 \cdot 4 & 4 \cdot 4 & 4 \cdot 5 & 5 \cdot 0 & 5 \cdot 5 & 6 \cdot 46 & 6 \cdot 00 & 6 \cdot 25 & 5 \cdot 34 & 7 \cdot 11 & 6 \cdot 32 & 5 \cdot 65 \\ \mathrm{O} & 4 & 8 & 7 & 8 & 9 & 4 & 6 & 5 & 7 & 4 & 3 & 9 & 4 & 1 & 0 & 5 & 6 & 2 & \end{array}$

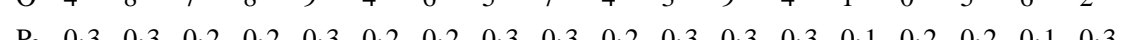
$\begin{array}{llllllllllllllllllllllllllll}\mathrm{O}_{5} & 1 & 7 & 4 & 8 & 1 & 8 & 9 & 2 & 7 & 0 & 2 & 6 & 0 & 2 & 4 & 6 & 8 & 0 & 0 \cdot 33 & 0.48 & 0.38 & 0.46 & 0 \cdot 28 & 0 \cdot 26 & 0.3\end{array}$ $\mathrm{F}$

$\mathrm{Cl}$ $\begin{array}{lllllllllllll}0 \cdot 0 & 0 \cdot 1 & 0 \cdot 0 & 0 \cdot 1 & 0 \cdot 0 & 0 \cdot 0 & 0 \cdot 1 & 0 \cdot 2 & 0 \cdot 1 & 0 \cdot 1 & 0 \cdot 1 & 0 \cdot 1\end{array}$ $\begin{array}{lllllllllllll}6 & 3 & 6 & 5 & 9 & 9 & 2 & 0 & 6 & 3 & 2 & 2\end{array}$ $\begin{array}{lllllllllllll}0 \cdot 0 & 0 \cdot 0 & 0 \cdot 0 & 0 \cdot 0 & 0 \cdot 0 & 0 \cdot 1 & 0 \cdot 0 & 0 \cdot 0 & 0 \cdot 0 & 0 \cdot 0 & 0 \cdot 0 & 0 \cdot 1\end{array}$ $\begin{array}{llllllllllll}8 & 8 & 9 & 9 & 8 & 2 & 9 & 7 & 8 & 7 & 9 & 3\end{array}$ $0.06<\mathrm{dl}$ $0.04 \quad 0 \cdot 00$

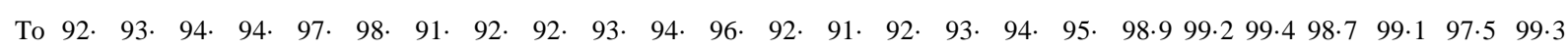
$\begin{array}{llllllllllllllllllllllllll}\text { tal } & 17 & 56 & 45 & 78 & 04 & 68 & 93 & 64 & 40 & 38 & 19 & 00 & 03 & 80 & 28 & 77 & 84 & 75 & 0 & 8 & 9 & 8 & 9 & 5 & 3\end{array}$

*Natural sample glass composition from Eschenbacher (1998). <dl, below detection limit. No glass analyses from experiment C_ATM 07 could be obtained owing to its high crystallinity level.

Analyses of glasses are reported in Table 7 and Fig. 7. Figure 7a shows the variation in glass composition for charges at $X_{\mathrm{H} 2 \mathrm{Oin}}=0$ and $X_{\mathrm{H} 2 \mathrm{Oin}}=0 \cdot 2$ with respect to temperature at a constant pressure of $100 \mathrm{MPa}$. Although the anorthoclase composition is fairly similar to the bulk-rock composition, its crystallization lowers the $\mathrm{SiO}_{2}$ and $\mathrm{CaO}$ contents of the residual melt while increasing that of $\mathrm{K}_{2} \mathrm{O}$ and keeping $\mathrm{Na}_{2} \mathrm{O}$ constant. The crystallization of clinopyroxene decreases $\mathrm{MgO}$ and results in a slight increase in $\mathrm{Al}_{2} \mathrm{O}_{3}$ with decreasing temperature. Glasses produced at high $f \mathrm{O}_{2}$ are similar to those produced at QFM, except for a significantly lower $\mathrm{FeO}_{\text {tot }}$ content (Table 7), owing in particular to a higher modal proportion of magnetite (Table 3). This also results in a lower Fe/Mg ratio of melts produced at high $f \mathrm{O}_{2}$ (in the range $3 \cdot 5-4 \cdot 5$ vs $4 \cdot 5-6 \cdot 5$ at QFM).

Figure $7 \mathrm{~b}$ shows the residual glass composition of reduced charges at $X_{\mathrm{H} 2 \mathrm{Oin}}=0$ and $X_{\mathrm{H} 2 \mathrm{Oin}}=$ $0 \cdot 2$ with respect to pressure at a constant temperature of $950^{\circ} \mathrm{C}$. Although most charges (at a given $X_{\mathrm{H} 2 \mathrm{O}}$ ) contain comparable modal abundance of minerals, the amount of anorthoclase does increase with decreasing pressure, causing an increase in $\mathrm{K}_{2} \mathrm{O}$ and a decrease in $\mathrm{CaO}$ content in the residual glass. The slight increase in $\mathrm{Na}_{2} \mathrm{O}$ with decreasing pressure is linked to the less albite-rich composition of the anorthoclase, which tends to be stable at lower pressure (to be discussed in a future study). Other major elements vary little (or in a non-systematic way) with decreasing pressure. 
In Fig. 7a and b, the composition of the natural glass is also plotted as a bold horizontal line. The natural glass composition is most closely reproduced at $950^{\circ} \mathrm{C}$ and pressures between 50 and $20 \mathrm{MPa}$, although the agreement is far from perfect and some oxide contents can be reproduced under different conditions. At atmospheric pressure, experimental charges produced between 925 and $1000^{\circ} \mathrm{C}$ are all close to the natural glass composition. The closest match is found at $975^{\circ} \mathrm{C}$.

\section{Discussion}

Constraints on the shallow plumbing system of Erebus

Isobaric phase-equilibrium experiments at $0 \cdot 1$ and $100 \mathrm{MPa}$, spanning a temperature range from 900 to $1025^{\circ} \mathrm{C}$, reproduce the natural Erebus phonolite phase proportions and compositions at a temperature of $950 \pm 25^{\circ} \mathrm{C}$. In addition, our phase-equilibrium data (Fig. 3) set a robust lower temperature limit of $925^{\circ} \mathrm{C}$ for the Erebus phonolite. Below this temperature, biotite would crystallize but it is not manifest in any Erebus lavas studied to date. Similarly, the lack of the amphibole-anorthoclase assemblage in Erebus' phonolitic products sets an upper limit on pressure of $200 \mathrm{MPa}$ (Fig. 4a). The temperature of $950 \pm 25^{\circ} \mathrm{C}$ is somewhat lower than the previously reported temperature of the Erebus phonolite lava of $1000^{\circ} \mathrm{C}$ (Kyle, 1977; Caldwell \& Kyle, 1994; Dunbar et al., 1994) but it probably falls within the uncertainties of the pyrometric measurement. It is consistent, too, with the maximum surface temperature of $923^{\circ} \mathrm{C}$ measured by mid-infrared imaging of the lava lake (Calkins et $a l ., 2008)$. This measurement should represent a minimum for the melt temperature because it was made from the crater rim and has not accounted for the attenuation of radiation from the lake by the intervening gas plume-filled atmosphere. It must also under-represent the magmatic temperature because it is a measure of the surface temperature; that is, of the surface crust or skin, which will have cooled relative to magma beneath through radiative heat loss.

We emphasize that, considering the dry character of the system (see below), we can rule out temperatures much lower than $950^{\circ} \mathrm{C}$ in the shallow plumbing system, as they would drive the system toward much higher crystallinities than observed (i.e. closer to the solidus, as documented by the $0 \cdot 1 \mathrm{MPa}$ experiments, Table 2). High crystallinities would also inhibit the style of magma convection observed (Molina et al., 2012). For instance, the $0 \cdot 1 \mathrm{MPa}$ charge at $925^{\circ} \mathrm{C}$ has nearly $70 \mathrm{wt} \%$ crystals (Table 2), which would increase magma viscosity by at least three orders of magnitude compared with that at $950^{\circ} \mathrm{C}$ (Champallier et al., 2008). We note that the appearance of biotite at $925^{\circ} \mathrm{C}$, almost irrespective of the water content, has been observed previously by Scaillet et al. (1995) for a peraluminous granite and by Bogaerts et al. (2006) for a metaluminous dacite.

As for the temperature of $1080^{\circ} \mathrm{C}$ reported by Burgisser et al. (2012) and used in their modelling of observed gas compositions for passive and explosive degassing from the lava lake, the discrepancy is substantial and, at this stage, we can only speculate on its cause. This high value was computed for ambient atmospheric pressure (in the Erebus crater, about 650 $\mathrm{hPa}$ ) from equilibrium constants for the reaction

$3 \mathrm{CO}+\mathrm{SO}_{2}=2 \mathrm{CO}_{2}+\mathrm{OCS}$

and field spectroscopic measurements of the abundances of each species. One possible scenario to explain why this procedure might overestimate the magmatic temperature is if the 
measured $\mathrm{SO}_{2}$ mass fraction in the gas plume is substantially higher than that in the magmatic gas. This could arise if $\mathrm{H}_{2} \mathrm{~S}$ represents a significant part of the sulphur in the magmatic gas but is instantaneously oxidized to $\mathrm{SO}_{2}$ on contact with air. In this case, the measured $\mathrm{SO}_{2}$ in the plume would not reflect the gas phase equilibrium reached in the magma. Indeed, $\mathrm{H}_{2} \mathrm{~S}$ has not been detected in the Erebus gas plume, despite the reduced magmatic conditions evident from the $\mathrm{CO}$ and $\mathrm{H}_{2}$ content of the plume. But if this is correct, it remains a puzzle as to why $\mathrm{H}_{2} \mathrm{~S}$ should oxidize in preference to $\mathrm{CO}$ and $\mathrm{H}_{2}$.

Isothermal phase-equilibrium experiments at a temperature of $950^{\circ} \mathrm{C}$ successfully reproduce the natural assemblage at all pressures below $200 \mathrm{MPa}$. Based on an average crustal density of $2.75 \mathrm{~g} \mathrm{~cm}^{-3}$, this is roughly equivalent to a depth of $7.5 \mathrm{~km}$. As stated above, this should correspond to the maximum depth from which phonolite similar to that erupted in the lava lake could be sourced. Recent imaging of the conduit by means of seismic interferometry and seismic tomography (Chaput et al., 2012; Zandomeneghi et al., 2013) has revealed a complex magmatic network within $\sim 4 \mathrm{~km}$ of the surface, but did not identify any large magma reservoir. Considering the stability in the chemistry and phase assemblage of the phonolite erupted from Erebus over the last $20 \mathrm{kyr}$ (Kelly et al., 2008b) a large, well-mixed phonolitic reservoir is expected. Thus, this hypothetical reservoir should be located between 4 and 7.5 $\mathrm{km}$ depth.

The oxidation state imposed in the majority of experimental runs lies in the range QFM to QFM - 2, within which the Fe/Mg partition coefficient of experimental clinopyroxene-liquid pairs is very close, if not identical, to that recorded by the natural pair (Table 4). This argues consistently for oxygen fugacity conditions being in the same range for the natural system.

Isothermal and isobaric phase experiments have been carried out for a range of water contents. Whereas the natural assemblage stability window varies with pressure, the melt water contents must always remain below $0.5 \mathrm{wt} \%$. At pressures lower than $100 \mathrm{MPa}$, for which our phase-equilibrium data are most detailed, melt water contents must be less than $0.25 \mathrm{wt} \%$. These results are fully consistent with FTIR spectroscopic analyses of anorthoclase-hosted melt inclusions, whose dissolved water contents do not exceed $0.2 \mathrm{wt} \%$ (Eschenbacher, 1998; Oppenheimer et al., 2011). Olivine-hosted melt inclusions from the parental basanite from which the Erebus phonolite is probably derived record $\mathrm{H}_{2} \mathrm{O}$ contents up to $1.75 \mathrm{wt} \%$ and up to $7000 \mathrm{ppm} \mathrm{CO}_{2}$ (Oppenheimer et al. 2011). The dry character of the phonolitic system most probably reflects continuous fluxing by $\mathrm{CO}_{2}$-rich fluids coming from more primitive magmas at greater depth that desiccate the shallower fractionated melts (but maintaining them close to the liquidus owing to heat brought in by the incoming bubbles). This is a consequence of open-conduit conditions with a hot magmatic column that allows permanent circulation of $\mathrm{CO}_{2}$-rich bubbles because of the low viscosity of the melt. It also stems from the fact that deep bubbles are always richer in $\mathrm{CO}_{2}$ than shallower ones, owing to the contrasting $\mathrm{CO}_{2}$ and $\mathrm{H}_{2} \mathrm{O}$ solubilities. Hence deep-sourced and $\mathrm{CO}_{2}$-rich bubbles disconnect easily (because of low viscosity) from their magma source and rise, scavenging water from the shallower magma. A possible contributing factor is that $\mathrm{H}_{2} \mathrm{O}$ diffuses faster than $\mathrm{CO}_{2}$, hence rising bubbles will become selectively enriched in $\mathrm{H}_{2} \mathrm{O}$ relative to $\mathrm{CO}_{2}$ owing to kinetic effects.

Possible evidence for $\mathrm{H}_{2} \mathrm{O}$ being drained out of the system can be inferred from surface measurements of gas emissions. Oppenheimer \& Kyle (2008) reported on $\mathrm{H}_{2} \mathrm{O}$ flux of $10 \mathrm{~kg}$ $\mathrm{s}^{-1}$ carried by the gas plume emitted from the lava lake. Taking an $\mathrm{H}_{2} \mathrm{O}$ content of $0.2 \mathrm{wt} \%$ in the melt would indicate a magma flux of $5000 \mathrm{~kg} \mathrm{~s}^{-1}$, or $\sim 2 \mathrm{~m}^{3} \mathrm{~s}^{-1}$ of dense magma. This 
estimate is a factor of five times higher than that estimated in the same fashion but based on the $\mathrm{HCl}$ emission rate and proportion of $\mathrm{Cl}$ exsolved from the melt. Although there are substantial uncertainties in these calculations, they tend to suggest that the $\mathrm{H}_{2} \mathrm{O}$ degassing at the surface cannot be accounted for solely by magma entering the lake; that is, some of the $\mathrm{H}_{2} \mathrm{O}$ has been sourced from deeper (un-erupted) magma, potentially scavenged from the melt by rising $\mathrm{CO}_{2}$-rich fluids.

\section{Comparison with other phonolitic volcanoes}

To date, six phase-equilibrium studies of the pre-eruptive conditions of phonolite eruptions have been reported. The bulk compositions of these phonolites are variable: $51 \cdot 3-60 \cdot 3 \mathrm{wt} \%$ $\mathrm{SiO}_{2} ; 0 \cdot 1-0.97$ wt $\% \mathrm{TiO}_{2} ; 18.77-22.80$ wt $\% \mathrm{Al}_{2} \mathrm{O}_{3} ; 1 \cdot 80-4.50$ wt $\% \mathrm{FeO}_{\mathrm{T}} ; 0 \cdot 13-0.23$ wt $\%$ $\mathrm{MnO} ; 0 \cdot 10-0.87$ wt $\% \mathrm{MgO} ; 0.64-5.90$ wt $\% \mathrm{CaO} ; 5 \cdot 23-10.69$ wt $\% \mathrm{Na}_{2} \mathrm{O} ; 5 \cdot 17-10.20$ wt $\% \mathrm{~K}_{2} \mathrm{O} ; \mathrm{Na}_{2} \mathrm{O} / \mathrm{K}_{2} \mathrm{O}$ of $0 \cdot 60-1 \cdot 81$. Accordingly, their associated phase stability diagrams differ markedly (see also Andújar \& Scaillet, 2012).

Table 8 summarizes the pre-eruptive conditions identified through comparable experimental studies of phonolitic systems. Supplementary Data Fig. DR1 shows the variation in major oxides with respect to the determined eruption temperature for all phonolites studied to date. Figure DR1 shows, unsurprisingly, that higher eruption temperatures are associated with higher $\mathrm{FeO}_{\mathrm{T}}, \mathrm{MgO}$ and $\mathrm{TiO}_{2}$, and lower $\mathrm{K}_{2} \mathrm{O}, \mathrm{SiO}_{2}$ and $\mathrm{Al}_{2} \mathrm{O}_{3}$ contents. $\mathrm{Na}_{2} \mathrm{O}$ and $\mathrm{CaO}$ contents do not vary consistently with temperature. The higher temperature and hence lower viscosity of the Erebus phonolite, and to a lesser extent that of Tenerife, tends to favour effusive over explosive eruptions, such as typify Vesuvius and Laacher See. The higher temperature and lower viscosity at Erebus also helps to sustain an active lava lake by conduit convection (Molina et al., 2012), probably driven by the density contrast of rising bubbly and volatile-rich magma and sinking degassed magma (e.g. Francis et al., 1993; Kazahaya et al., 1994). Although reported pressure ranges are comparable for all the phonolites examined, in comparison with other volcanoes, the phonolite erupted from Erebus is consistently and significantly hotter. 
Table 8 : Comparison of pre-eruptive conditions determined for various phonolitic systems

\begin{tabular}{|c|c|c|c|c|c|c|c|c|c|c|c|}
\hline $\begin{array}{l}\text { Volcano or } \\
\text { eruption: }\end{array}$ & Mercato & Avellino & Pompeii & Pollena & Laach & er See ho & orizons & Kerguelen & $\begin{array}{c}\text { Tenerife, } \\
\text { Lavas } \\
\text { Negras }\end{array}$ & $\begin{array}{l}\text { Tenerife, } \\
\text { El Abrigo }\end{array}$ & Erebus \\
\hline Age: & 8010 bp & 3360 bp & ad 79 & ad 472 & LLST & MLST & ULST & $\begin{array}{l}\text { Upper } \\
\text { Miocene }\end{array}$ & $1150 \mathrm{bp}$ & 190 ka & $\begin{array}{l}20 \text { ka to } \\
\text { present }\end{array}$ \\
\hline $\begin{array}{l}\text { Temperature } \\
\left({ }^{\circ} \mathrm{C}\right)\end{array}$ & $785 \pm 10$ & $785 \pm 10$ & $\begin{array}{l}815 \pm \\
10\end{array}$ & $\begin{array}{l}800 \pm \\
10\end{array}$ & $\begin{array}{l}720 \pm \\
20\end{array}$ & $\begin{array}{l}760- \\
780\end{array}$ & $\begin{array}{l}840- \\
870\end{array}$ & 800 & $00=$ & $825 \pm$ & $950 \pm 25$ \\
\hline $\begin{array}{l}\text { Pressure } \\
\text { (kbar) }\end{array}$ & $2 \pm 0 \cdot 2$ & $2 \pm 0 \cdot 2$ & $2 \pm 0 \cdot 2$ & 1 & $2 ?$ & $2 ?$ & $2 ?$ & $2-2 \cdot 5$ & $1 \cdot 5 \pm 0 \cdot 5$ & $1 \cdot 3 \pm 0 \cdot 5$ & $<2$ \\
\hline wt $\% \mathrm{H}_{2} \mathrm{O}$ & $7 \pm 0 \cdot 5$ & $5-5 \cdot 5$ & $6-6 \cdot 5$ & $3-4$ & $?$ & $>6$ & $<6$ & $4-6$ & $2 \cdot 5-3 \cdot$ & $3 \pm 1$ & $<0.5$ \\
\hline $\begin{array}{l}\text { Oxidation } \\
\text { state }\end{array}$ & $\begin{array}{l}\mathrm{NNO}+ \\
1\end{array}$ & $\begin{array}{l}\mathrm{NNO}+ \\
1\end{array}$ & $\begin{array}{l}\mathrm{NNO}+ \\
1\end{array}$ & $\begin{array}{l}\mathrm{NNO}+ \\
1\end{array}$ & $\begin{array}{l}\text { NNO } \\
+2 ?\end{array}$ & $\begin{array}{l}\mathrm{NNO}+ \\
2 ?\end{array}$ & $\begin{array}{l}\text { NNO } \\
+2 ?\end{array}$ & $\begin{array}{l}\mathrm{NNO}+1 \text { to } \\
\mathrm{NNO}+2\end{array}$ & $\mathrm{NNO}+1 ?$ & $\mathrm{NNO} \pm 1$ & $\begin{array}{l}\text { QFM to } \\
\text { QFM - } 1\end{array}$ \\
\hline Reference & Scaille & tal. $(20$ & & & Bern & et & 001) & $\begin{array}{l}\text { Freise et al. } \\
(2003)\end{array}$ & $\begin{array}{l}\text { Andújar et } \\
\text { al. (2009) }\end{array}$ & $\begin{array}{l}\text { Andújar et } \\
\text { al. (2008) }\end{array}$ & $\begin{array}{l}\text { This } \\
\text { study }\end{array}$ \\
\hline
\end{tabular}

- Berndt et al. (2001) studied phonolite from the Laacher See tephra under conditions of $760-880^{\circ} \mathrm{C}, 200-400 \mathrm{MPa}, \mathrm{NNO}$ to $\mathrm{NNO}+2 \cdot 3$, and 6-8 wt $\% \mathrm{H}_{2} \mathrm{O}$. Harms et al. (2004) studied similar tephra under more restricted conditions of $725-800^{\circ} \mathrm{C}, 750$ 1750 bar, $\mathrm{NNO}+1$ and uncertain $\mathrm{H}_{2} \mathrm{O}$ content. Freise et al. (2003) studied Upper Miocene phonolite lava from Kerguelen under conditions of $700-900^{\circ} \mathrm{C}, 100-500$ $\mathrm{MPa}$, NNO to $\mathrm{NNO}+2 \cdot 3$ and $0 \cdot 5-8 \mathrm{wt} \% \mathrm{H}_{2} \mathrm{O}$. Scaillet et al. (2008) studied four Vesuvius eruptions (Mercado, Avellino, Pompeii and Pollena) under conditions of $750-950^{\circ} \mathrm{C}, 50-350 \mathrm{MPa}, \mathrm{NNO}+1$ and $2-7 \cdot 5 \mathrm{wt} \% \mathrm{H}_{2} \mathrm{O}$. Finally two experimental studies by Andújar et al. (2008) and Andújar et al. (2009) looked at the pre-eruptive conditions of the El Abrigo ignimbrite and Lavas Negras flow respectively, on Tenerife. Andújar et al. (2008) explored conditions of 700-900 ${ }^{\circ} \mathrm{C}, 50-250$ bar, NNO +1 to QFM, and 1.5-10 wt \% $\mathrm{H}_{2} \mathrm{O}$. Andújar et al. (2009) looked at conditions of 750$925^{\circ} \mathrm{C}, 100-250 \mathrm{MPa}, \mathrm{NNO}+1$ and $1 \cdot 3-10 \mathrm{wt} \% \mathrm{H}_{2} \mathrm{O}$.

Particularly striking compared with the other phonolitic systems, however, is the much lower water content for the Erebus phonolite and its distinctly more reduced character. These differences partly reflect the geodynamic setting of Erebus, located within a rift system above a hotspot, possibly a mantle plume (compare this situation with the subduction-related setting of some of the other phonolitic volcanoes considered). Another distinctive characteristic of the Erebus phonolite is its abundance of $\mathrm{CO}_{2}$ (Eschenbacher, 1998; Oppenheimer et al., 2011), compared with other phonolitic systems such as Vesuvius (Cioni, 2000). The continuous fluxing of the upper magmatic system by $\mathrm{CO}_{2}$-rich gas, promoted perhaps by the elevated temperature and lower melt viscosity, may provide a significant source of heat (e.g. Bachmann \& Bergantz, 2003) and is thus an important contributing factor for maintaining isothermal conditions over long periods. $\mathrm{CO}_{2}$ fluxing has also previously been hypothesized to occur beneath Stromboli (Allard, 2010) and Etna (e.g. Collins et al., 2009). Within this context, it is also worth noting that, despite the continuous $\mathrm{CO}_{2}$ flushing of the Erebus magma system and evidence for conduit convection and associated dynamical effects (Oppenheimer et al., 2009, 2011), the crystal-melt equilibrium is fundamentally maintained in this system, as documented by the good agreement between our phase-equilibrium constraints and the main petrological attributes of the Erebus phonolite. 


\section{Conclusions}

We have constrained the conditions of the shallow plumbing system of Erebus volcano in $P$ $T-\mathrm{H}_{2} \mathrm{O}-f \mathrm{O}_{2}$ space. The natural assemblage observed in the eruptive products has been successfully reproduced by phase-equilibrium experiments at a temperature of $950 \pm 25^{\circ} \mathrm{C}$, and at pressures $<200 \mathrm{MPa}$. Recent seismological investigations appear to rule out the existence of any large magma reservoir shallower than $4 \mathrm{~km}$, suggesting that if such a magma body exists it is located at a depth between 4 and $7.5 \mathrm{~km}$, where it would have a water content $<0.5 \mathrm{wt} \%$ and an $f \mathrm{O}_{2}$ between QFM and QFM - 1. The temperature of the phonolitic lava or magma is $\sim 50^{\circ} \mathrm{C}$ lower than that previously accepted, which has significant implications for interpreting the composition of gases released from the lava lake, and for physical modelling of the magmatic system (e.g. melt viscosity would be approximately three times higher at $950^{\circ} \mathrm{C}$ than at $1000^{\circ} \mathrm{C}$ ). Compared with other phonolitic magmas, the Erebus phonolite is consistently drier, hotter and more reduced.

Taking into account the exceptional chemical and modal stability of the Erebus phonolite over the last $20 \mathrm{kyr}$ (Kelly et al., 2008b), the strong constraint we have imposed on the temperature of the lava to re-create the natural rock implies that the heat supply beneath the volcano must have remained extremely stable over this time period, never allowing the magma to cool below $925^{\circ} \mathrm{C}$. Such thermal stability and evidence of $\mathrm{CO}_{2}$ fluxing argues for a plumbing system directly connected to the melting source region in the mantle, via one or several magma reservoirs (Oppenheimer et al., 2011). Heat and fluid loss at the top of the system is constantly compensated by heat and fluid input from the source region preventing the shallow plumbing system from cooling over time.

\section{Funding}

This research was supported by grants ANT0838817 and ANT1142083 from the Office of Polar Programs (National Science Foundation), and grant 202844 ('DEMONS') from the European Research Council (FP7). Y.M. was additionally supported by the University of Cambridge Home and EU Scholarship Scheme in addition to the Philip Lake and William Vaughan Lewis funds from the Department of Geography, University of Cambridge. C.O. also acknowledges support from the National Centre for Earth Observation (NERC NE/F001487/1 'Dynamic Earth and Geohazards' theme).

\section{Acknowledgements}

We are very grateful to Joan Andújar, Rémi Champallier, Marina Alletti, Anita Cadoux, Mickael Laumonier, Giada Iacono Marziano, David Sifre, Nolwenn Le-gall, Fabrice Gaillard and Michel Pichavant for their help with various instruments and for inspiring discussions. Special thanks also go to Ida Di Carlo and Iris Buisman for invaluable help with the SEM and electron probe. We are also grateful to Marjorie Wilson, Ray Macdonald and an anonymous reviewer for their constructive reviews of the original work. 


\section{References}

Andújar J, Scaillet B . Relationships between pre-eruptive conditions and eruptive styles of phonolite-trachyte magmas. Lithos 2012;152:122-131.

Andújar J, Costa F, Martí J, Wolff J A, Carroll M R . Experimental constraints on preeruptive conditions of phonolitic magma from the caldera-forming El Abrigo eruption, Tenerife (Canary Islands). Chemical Geology 2008;257(3-4):173-191. doi:10.1016/j.chemgeo.2008.08.012.

Andújar J, Costa F, Martí J. Magma storage conditions of the last eruption of Teide volcano (Canary Islands, Spain). Bulletin of Volcanology 2009;72(4):381-395. doi:10.1007/s00445009-0325-3.

Allard P. A $\mathrm{CO}_{2}$-rich gas trigger of explosive paroxysms at Stromboli basaltic volcano, Italy. Journal of Volcanology and Geothermal Research 2010;189(3-4):363-374.

Aster R, Zandomeneghi D, Mah S, McNamara S, Henderson D B, Knox H, Jones K. Moment tensor inversion of very long period seismic signals from Strombolian eruptions of Erebus Volcano. Journal of Volcanology and Geothermal Research 2008;177:635-647.

Bachmann O, Bergantz G W. Rejuvenation of the Fish Canyon magma body: a window into the evolution of large-volume silicic magma systems. Geology 2003;31:789-792.

Berndt J, Holtz F, Koepke J. Experimental constraints on storage conditions in the chemically zoned phonolitic magma chamber of the Laacher See volcano. Contributions to Mineralogy and Petrology 2001;140(4):469-486. doi:10.1007/PL00007674.

Bogaerts M, Scaillet B, Vander Auwera J. Phase equilibria of the Lyngdal Granodiorite (Norway): implications for the origin of oxidised A-type magmas. Journal of Petrology 2006;12:2405-2431. doi:10.1093/petrology/egl049.

Burgisser A, Oppenheimer C, Alletti M, Kyle P R. Backward tracking of gas chemistry measurements at Erebus volcano. Geochemistry, Geophysics, Geosystems 2012;12(11):Q11010. doi:10.1029/2012GC00424.

Caldwell D, Kyle P R. Mineralogy and geochemistry of ejecta erupted from Mount Erebus, Antarctica between 1972 and 1986. In: Kyle P R, editor. Volcanological and Environmental Studies of Mount Erebus. American Geophysical Union, Antarctic Research Series. Vol. 66. 1994. p. 147-162.

Calkins J, Oppenheimer C, Kyle P R. Ground-based thermal imaging of lava lakes at Erebus volcano, Antarctica. Journal of Volcanology and Geothermal Research 2008; 177:695-704.

Carroll M R, Blank J G. The solubility of $\mathrm{H}_{2} \mathrm{O}$ in phonolitic melts. American Mineralogist 1997;82:549-556.

Champallier R, Bystricky M, Arbaret L. Experimental investigation of magma rheology at $300 \mathrm{MPa}$ : from pure hydrous melt to $76 \mathrm{vol}$. \% of crystals. Earth and Planetary Science Letters 2008;267:571-583. 
Chaput J A, Zandomeneghi D, Aster R C, Knox H, Kyle P R. Imaging of Erebus volcano using body wave seismic interferometry of Strombolian eruption coda. Geophysical Research Letters 2012;39. doi:10.1029/2012GL050956.

Cioni R. Volatile content and degassing processes in the AD 79 magma chamber at Vesuvius (Italy). Contributions to Mineralogy and Petrology 2000;140:40-54.

Collins S J, Pyle D M, Maclennan J. Melt inclusions track pre-eruption storage and dehydration of magmas at Etna. Geology 2009;37(6):571-574.

Dall'Agnol R, Scaillet B, Pichavant M. An experimental study of a lower Proterozoic A-type granite from the eastern Amazonian craton, Brazil. Journal of Petrology 1999;40(11):16731698.

Devine J D, Gardner J E, Brack H P, Layne G D, Rutherford M J. Comparison of microanalytical methods for estimating $\mathrm{H}_{2} \mathrm{O}$ contents of silicic volcanic glasses. American Mineralogist 1995;80:319-328.

Di Carlo I, Pichavant M, Rotolo S G, Scaillet B. Experimental crystallization of a high-K arc basalt: the Golden Pumice, Stromboli Volcano (Italy). Journal of Petrology 2006;47(7):13171343.

Dunbar N W, Cashman K, Dupre R. Crystallization processes of anorthoclase phenocrysts in the Mount Erebus magmatic system: evidence from crystal composition, crystal size distributions and volatile contents of melt inclusions. In: Kyle P R, editor. Volcanological and Environmental Studies of Mt. Erebus. American Geophysical Union, Antarctic Research Series. Vol. 66. 1994. p. 129-146.

Eschenbacher A. 1998. Open-system degassing of a fractionating, alkaline magma, Mount Erebus, Ross Island, Antarctica. Master's thesis, New Mexico Institute of Mining and Technology, Socorro.

Esser R P, Kyle P R, McIntosh W C. ${ }^{40} A r /^{39} A r$ dating of the eruptive history of Mount Erebus, Antarctica: volcano evolution. Bulletin of Volcanology 2004;66:671-686.

Francis P W, Oppenheimer C, Stevenson D. Endogenous growth of persistently active volcanoes. Nature 1993;366:554-557.

Freise M, Holtz F, Scoates J, Leyrit H. Experimental constraints on the storage conditions of phonolites from the Kerguelen Archipelago. Contributions to Mineralogy and Petrology 2003;145(6):659-672. doi:10.1007/s00410-003-0453-2.

Gerst A, Hort M, Kyle P R, Voge M. 4D velocity of Strombolian eruptions and man-made explosions derived from multiple Doppler radar instruments. Journal of Volcanology and Geothermal Research 2008; 177:648-660.

Gerst A, Horst M, Aster R, Johnson J, Kyle P R. The first second of a Strombolian volcanic eruption - Energies, pressures, infrasound. Journal of Geophysical Research 2013. (in review). 
Gupta S, Zhao D P, Rai S S. Seismic imaging of the upper mantle under the Erebus hotspot in Antarctica. Gondwana Research 2009;16:109-118.

Harms E, Gardner J E, Schmincke H-U. Phase equilibria of the Lower Laacher See Tephra (East Eifel, Germany): constraints on pre-eruptive storage conditions of a phonolitic magma reservoir. Journal of Volcanology and Geothermal Research 2004;134(1-2):125-138.

Harpel C J, Kyle P R, Esser R P, McIntosh W C, Caldwell D A. ${ }^{40}$ Ar ${ }^{\beta 9}$ Ar dating of the eruptive history of Mount Erebus, Antarctica: summit flows, tephra, and caldera collapse. Bulletin of Volcanology 2004;66:687-702.

Harpel C J, Kyle P R, Dunbar N W. Englacial tephrostratigraphy of Erebus volcano, Antarctica. Journal of Volcanology and Geothermal Research 2008;177:549-568.

Kazahaya K, Shinohara H, Saito G. Excessive degassing of Izu-Oshima volcano: magma convection in a conduit. Bulletin of Volcanology 1994;56:207-216.

Kelly P, Dunbar N, Kyle P, McIntosh W. Refinement of the late Quaternary geologic history of Erebus volcano, Antarctica using ${ }^{40} \mathrm{Ar}{ }^{39} \mathrm{Ar}$ and ${ }^{36} \mathrm{Cl}$ age determinations. Journal of Volcanology and Geothermal Research 2008a;177:569-577.

Kelly P J, Kyle P R, Dunbar N W, Sims K W W. Geochemistry and mineralogy of the phonolite lava lake, Erebus volcano, Antarctica: 1972-2004 and comparison with older lavas. Journal of Volcanology and Geothermal Research 2008b;177:589-605.

Kyle P R. Mineralogy and glass chemistry of recent volcanic ejecta from Mt. Erebus, Ross Island, Antarctica. New Zealand Journal of Geology 1977;20:1123-1146.

Kyle P R. McMurdo Volcanic Group Western Ross Embayment: Introduction. In: LeMasurier W, Thompson J, editors. Volcanism of the Antarctic Plate and Southern Oceans. 1990a. Antarctic Research Series, Vol. 48. American Geophysical Union, pp. 18-25.

Kyle P R. Erebus volcanic Province: Summary. In: LeMasurier W, Thompson J, editors. Volcanism of the Antarctic Plate and Southern Oceans. 1990b. Antarctic Research Series, Vol. 48. American Geophysical Union, pp. 81-88.

Kyle P, Dibble R, Giggenbach W, Keys J. Volcanic activity associated with the anorthoclase phonolite lava lake, Mt. Erebus, Antarctica. In: Craddock C, editor. Antarctic Geosciences. Madison, WI: University of Wisconsin Press; 1982. p. 735-745.

Kyle P R, Moore J A, Thirlwall M F. Petrologic evolution of anorthoclase phonolite lavas at Mount Erebus, Ross Island, Antarctica. Journal of Petrology 1992;33:849-875.

Kyle P R, Sybeldon L M, Mcintosh W C, Meeker K, Symonds R. Sulfur dioxide emission rates from Mount Erebus, Antarctica. In: Kyle P R, editor. Volcanological and Environmental Studies of Mount Erebus. American Geophysical Union, Antarctic Research Series. Vol. 66. 1994. p. 69-82.

Le Bas M J, Lemaitre R W, Streckeisen A, Zanettin B. A chemical classification of volcanicrocks based on the total alkali-silica diagram. Journal of Petrology 1986;27(3):745-750. 
Molina I, Burgisser A, Oppenheimer C. Origin of steady convection in Erebus lava lake, Antarctica: The effects of crystals in open and closed systems. Journal of Geophysical Research 2012.

Moussallam Y, Oppenheimer C, Aiuppa A, Giudice G, Moussallam M, Kyle P. Hydrogen emissions from Erebus volcano, Antarctica. Bulletin of Volcanology 2012;74(9):2109-2120.

Oppenheimer C, Kyle P R. Probing the magma plumbing of Erebus volcano, Antarctica, by open-path FTIR spectroscopy of gas emissions. Journal of Volcanology and Geothermal Research 2008; 177:743-754.

Oppenheimer C, Lomakina A S, Kyle P R, Kingsbury N G, Boichu M. Pulsatory magma supply to a phonolite lava lake. Earth and Planetary Science Letters 2009;284:392-398.

Oppenheimer C, Moretti R, Kyle P R, Eschenbacher A, Lowenstern J B, Hervig R L, Dunbar $\mathrm{N}$ W. Mantle to surface degassing of alkalic magmas at Erebus volcano, Antarctica. Earth and Planetary Science Letters 2011;306:261-271. doi:10.1016/j.epsl.2011.04.005.

Prouteau G, Scaillet B. Experimental constraints on the origin of the 1991 Pinatubo dacite. Journal of Petrology 2003;44(12):2203-2241.

Scaillet B, Pichavant M, Roux J, Humbert G, Lefèvre A. Improvement of the Shaw membrane technique for measurement and control of $f_{\mathrm{H}_{2}}$ at high temperatures and pressures. American Mineralogist 1992;77:647-655.

Scaillet B, Pichavant M, Roux J. Experimental crystallization of leucogranite magmas. Journal of Petrology 1995;36(3):663-705.

Scaillet B, Pichavant M, Cioni R. Upward migration of Vesuvius magma chamber over the past 20,000 years. Nature 2008;455(7210):216-219. doi:10.1038/nature07232.

Schmidt B C, Behrens H. Water solubility in phonolite melts: Influence of melt composition and temperature. Chemical Geology 2008;256(3-4):259-268.

Taylor J R, Wall V J, Pownceby M I. The calibration and application of accurate redox sensors. American Mineralogist 1992;77:284-295.

Zandomeneghi D, Aster R, Kyle P R, Barclay A, Chaput J, Knox H. Internal structure of Erebus volcano, Antarctica imaged by high-resolution active-source seismic tomography and coda interferometry. Journal of Geophysical Research 2013;118:1067-1078. 